Bull. Fac. Agric., Cairo Univ., 68: 23-35(2017).

\title{
IMPACT OF HUSBAND MIGRATION ON THE CHANGE OF FAMILY BURDENS FOR RURAL WOMAN (SOCIAL STUDY IN SHARKIA GOVERNORATE EGYPT)
}

(Received: 26.12.2016)

\author{
By \\ H. A.A. El-Deeb and S. M. Sh. Newaser \\ Agriculture Economic Department, Branch of Rural Sociology., Faculty of Agriculture, \\ Zagazig University, Egypt
}

\begin{abstract}
The present study aimed to explore the actual family burdens (House hold duties) of rural woman and their changes as a result of migration of her husband, to identify the change in the behavior of the husband as a result of migration, to identify the causes leading to the migration of the husband outside the local community define the relationship between the family burdens of rural woman before and after the migration of her husband and the independent variables. The study depended on Judgemental Sample 142 housewives of husbands traveler families, 67 heads of families of Alackheoh village in Husseiniya center, 75 heads of families of Alkhaddarah village in Abrahamia Centre. The data collection used a questionnaire by personal interview, starting from August until mid-October 2016. Data were analyzed using frequencies and percentages, alpha Cronbach's coefficient, weighed mean, Pearson correlation coefficient, Chi-square test, calculate the percentage change. The study showed the following findings: There was a change in bearing the family burdens by rural woman as a result of her husband travel, and this change will increase the family burden on rural women as a result of migration, whether private or sons economic burdens or social costs or burdens for the agricultural aspect of these burdens. There is a positive correlation between the family burdens of rural women before her husband migration and the degree of domestic violence, a negative relationship with: the degree of affiliation of prisoners, the degree of contact of prisoners at the moral level of 0.01 . And there is a negative correlation between the family burdens of rural women after her husband migration and: the monthly income of the family, the trend toward travel outside the community at the moral level of 0.01 .
\end{abstract}

Key words: husband migration, change, family burdens (House hold duties), Sharkia Governorate.

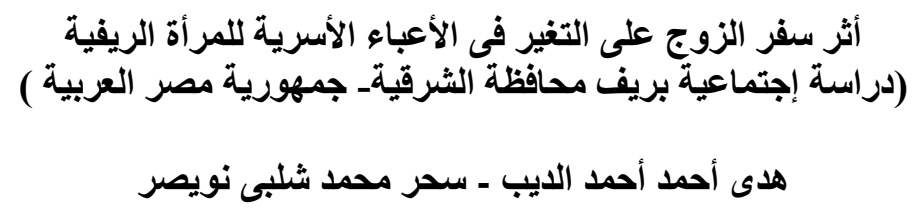

قسم الإقتصاد الزراعى- شعبة الاجتماع الريفى والإرشاد الزراعى- كلية الزراعة ـ جامعة الزقازيق ـ مصر

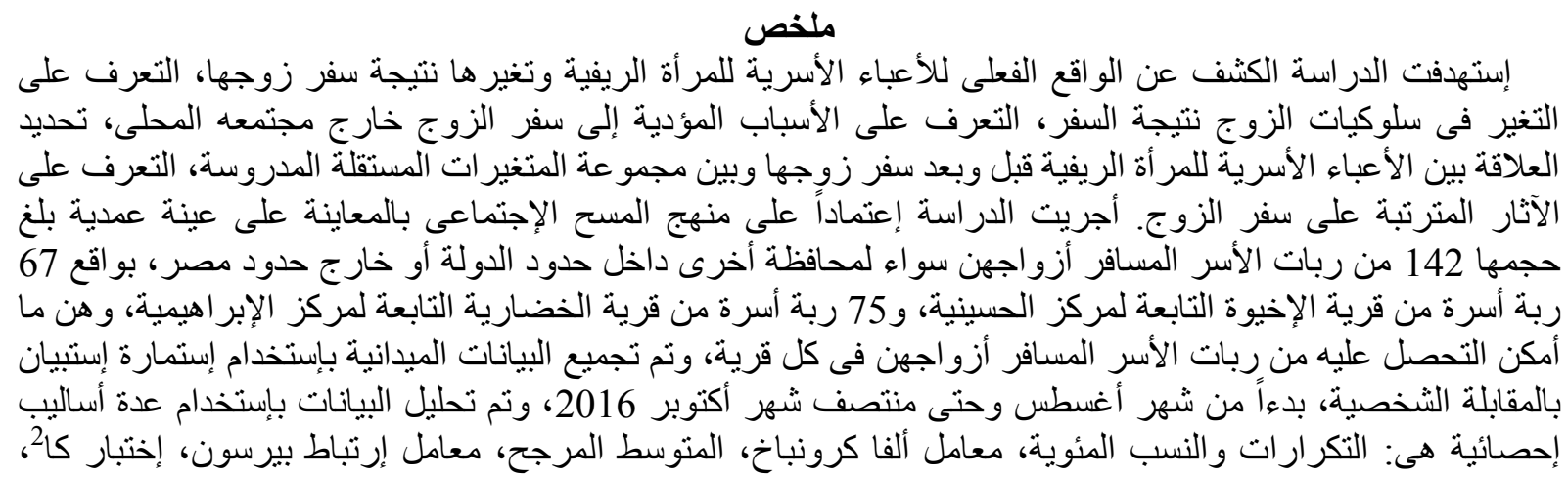




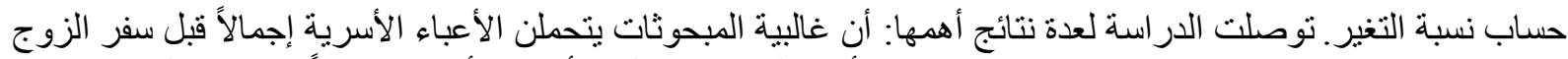

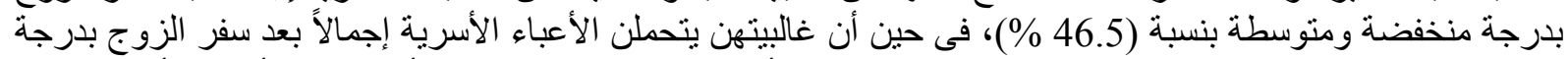

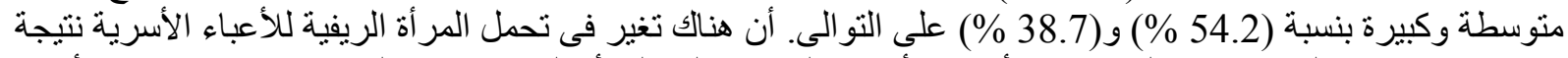

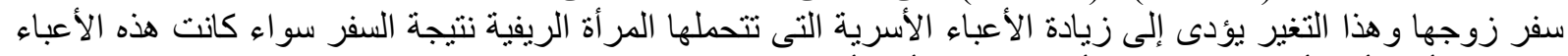

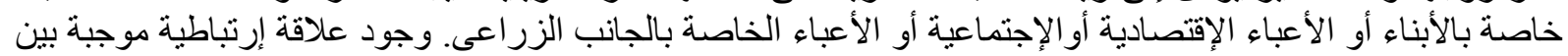

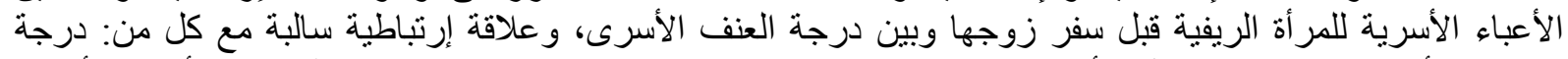

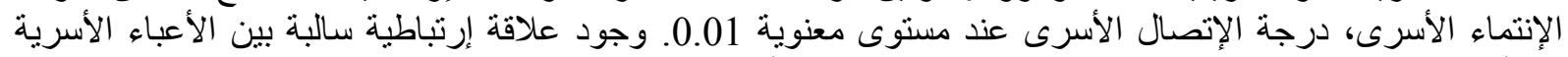

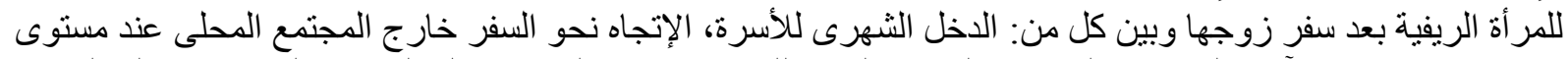

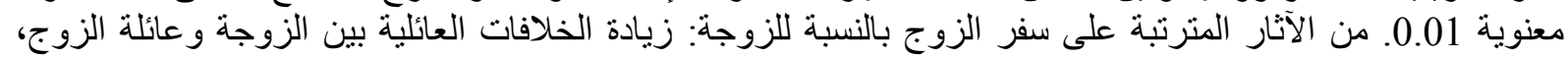

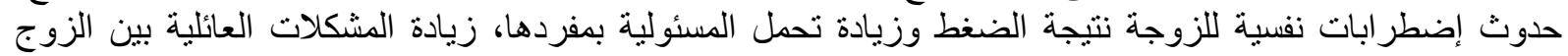

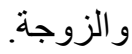

(حافظ، 2008)، حيث يحتل الأب قمة الهرم فى البناء

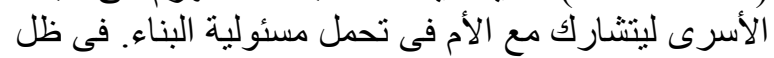

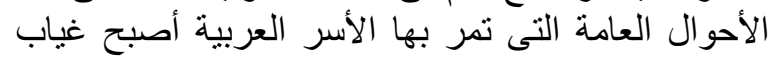

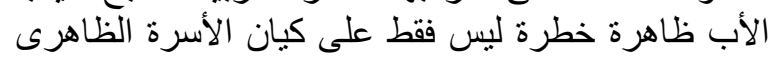

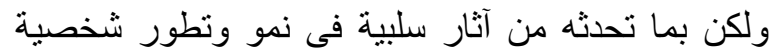

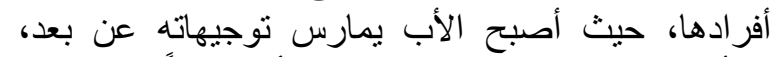
و الأب له دور لا يمكن إسناده إلى الأم خاصةًة في مرحلة الإنة

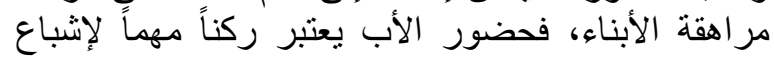

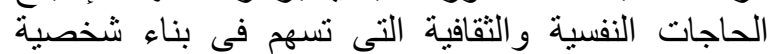

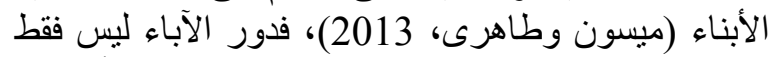

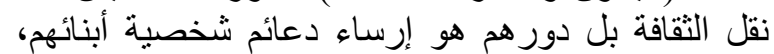

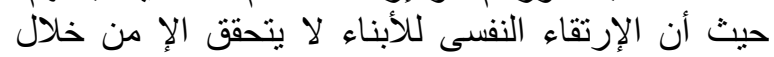

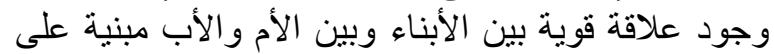

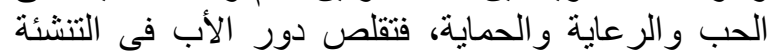

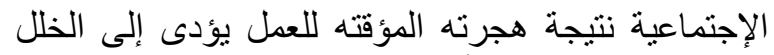

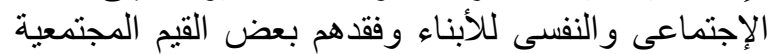

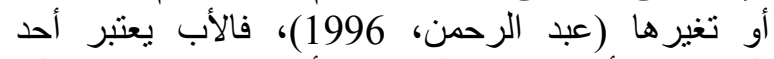

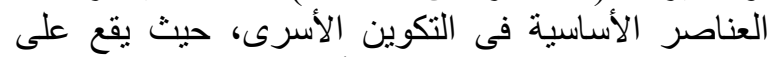

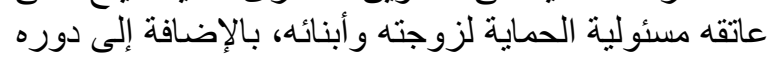

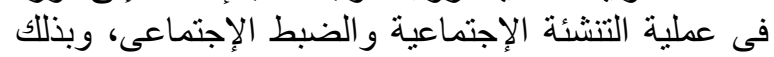

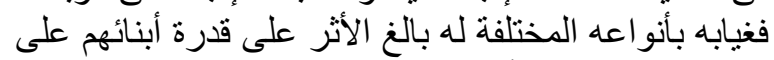

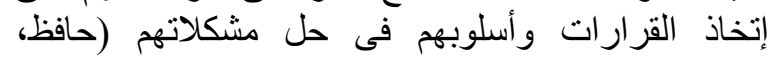

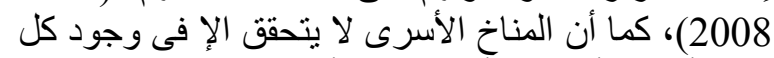

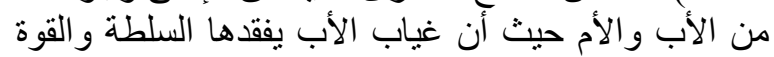
و الحماية ويزيد من مسؤليات ربة الأب الأسرة (عبد الرحمن، الرابة

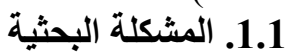

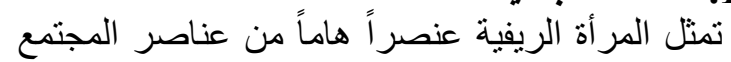

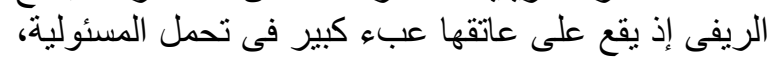

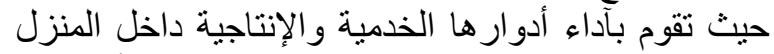

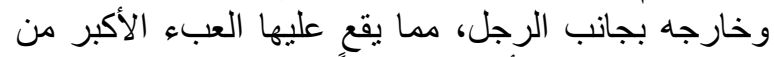

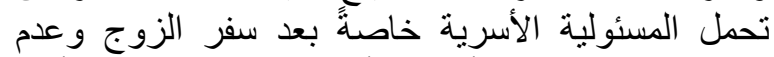

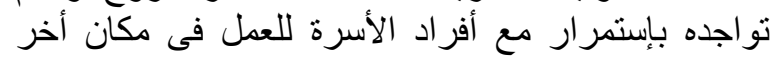

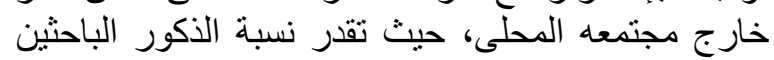

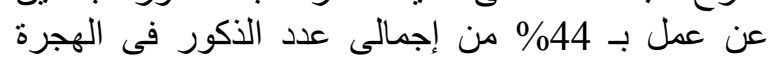

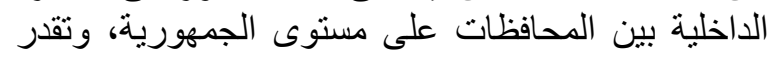

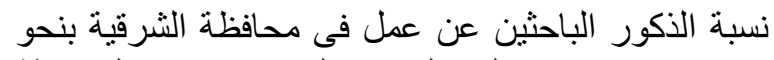
50.9 \% من إجمالى الذكور الذين ينركون المحافظة

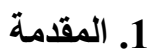

عاش الإنسان عبر السنين باحثاً عن الإستقرار و الأمان

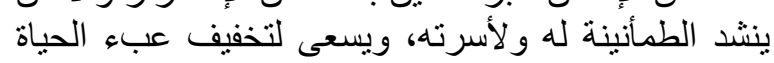

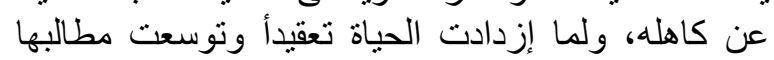

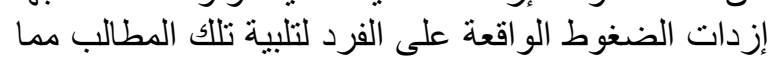

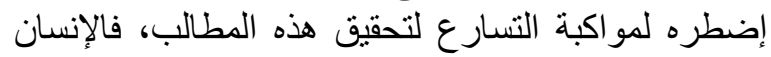

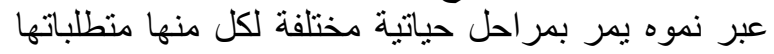

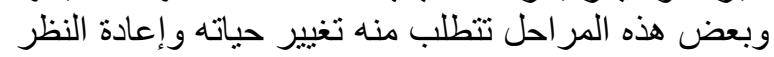
فى إسلوب معيشته لتحقيق التكيف الملائم لنفسه وإعاده وأسرته

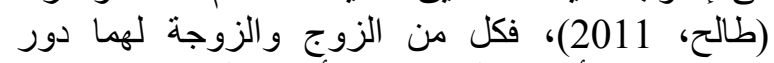

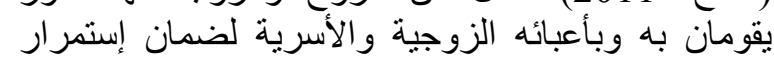

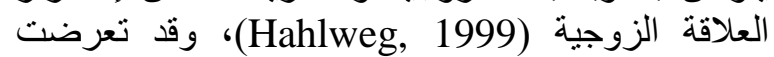

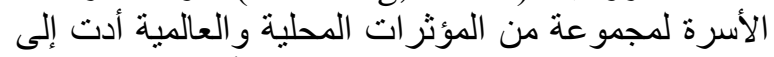

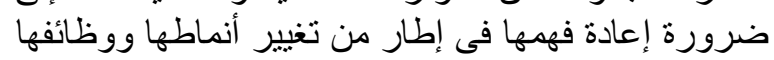

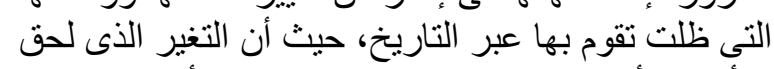

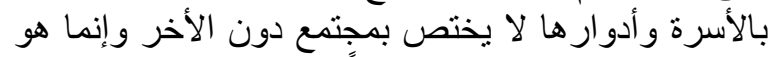

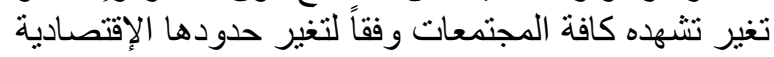

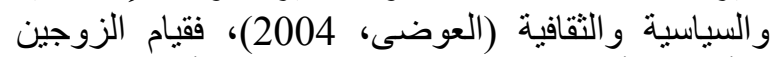

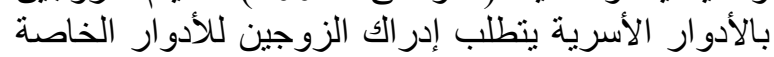

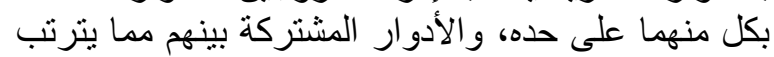

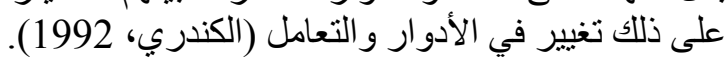

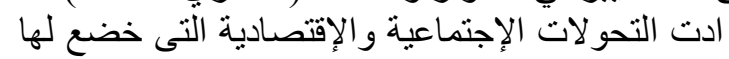

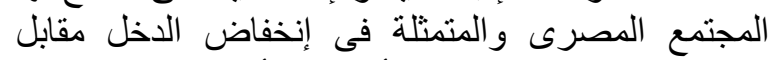

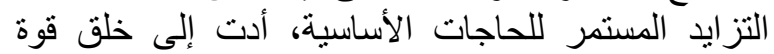

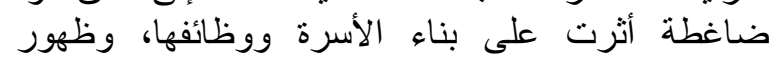

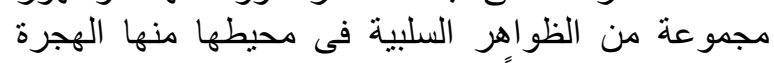

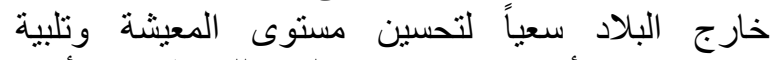

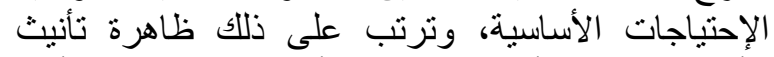

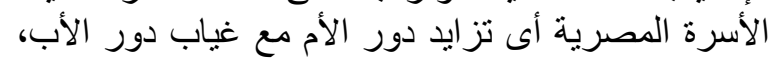

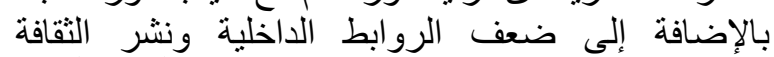

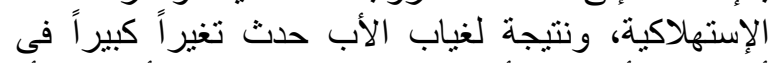

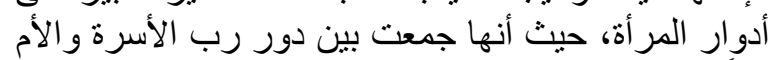

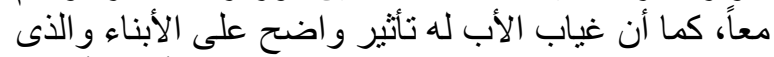

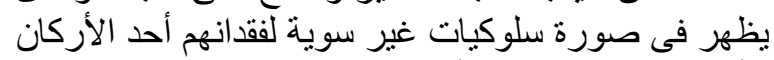

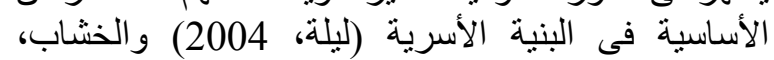

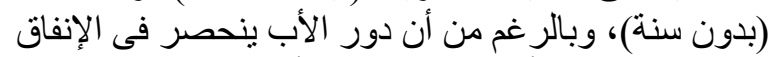

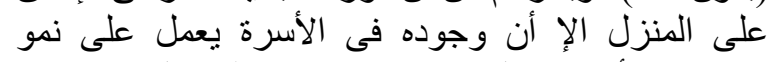

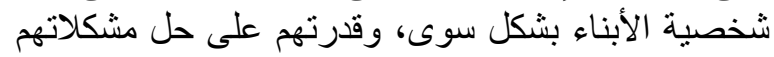




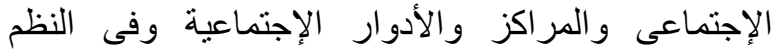
و الأنساق و الأجهزة الإجتماعية خلال فترة معينة من الزمن.

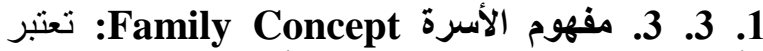

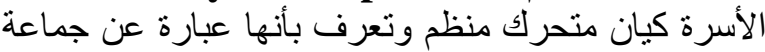

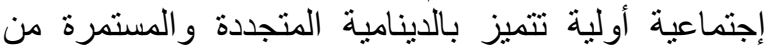

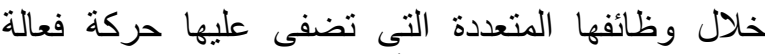

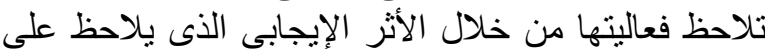

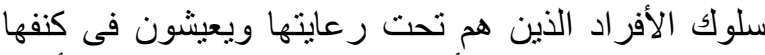
(عزى، 2014)> كما أنشار حجازى (2015) إلى اللى الأسرة

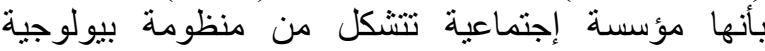

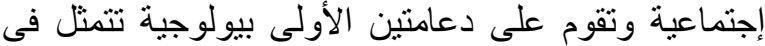

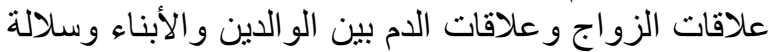

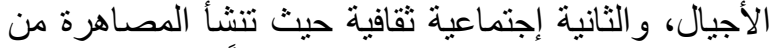
خلال الزواج ويقوم الرباط الزواجى تبعاً لقوانية النين الأحوال الثخصية حيث يتم الإعتر اف بهاط الثها

1 Concept

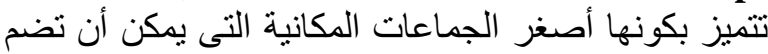

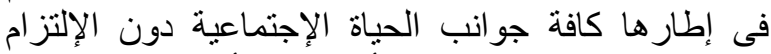

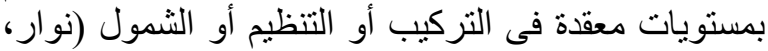

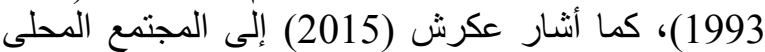

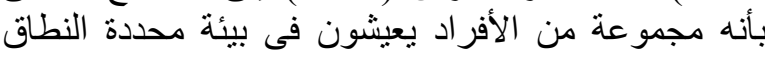

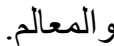
1. 3. 5. النظريات الإجتماعية لتفسير الأعباء الأسرية للمرأة الريفية: هناك بعض الإنياعة النظريات التى تركز على الاعلى الألى

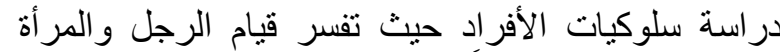

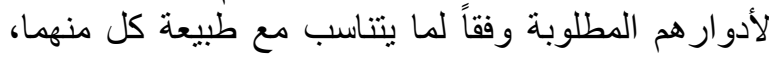

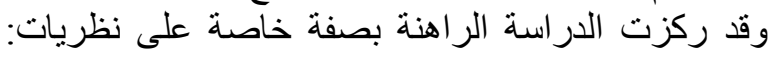
الدور الإجتماعى، نظرية التغير الإجتماعى، النظرية التية

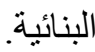

1. 3. 5. 1. نظرية الدور الاجتماعى: لا يعيش الإنسان فى في فئم

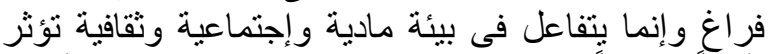

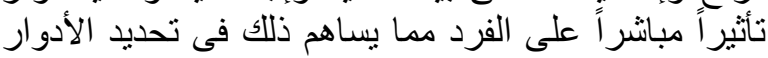

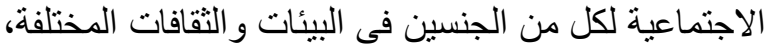
حيث أن الثقافة هى التى تحدد الجنى الدور الأنثوى و السلوك

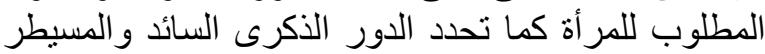

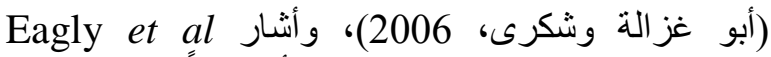
(Harrison and Lynch, 2005)

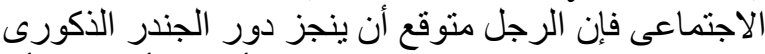

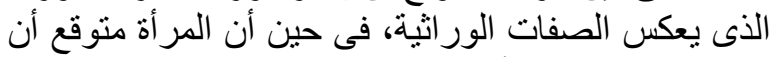

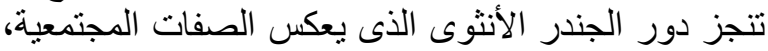

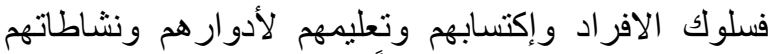
وممارستهم اليومية يتحدد وفقاً لإحتياجات الفرد الليودة البيولوجية

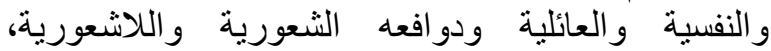

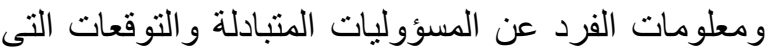

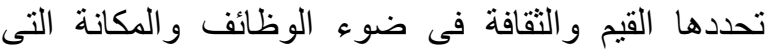

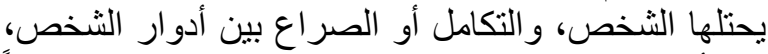

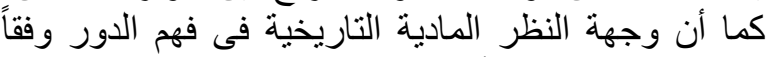

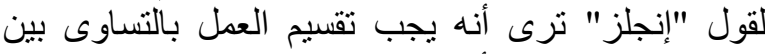
الرجال و النساء حيث أن الجميع يشتركون في عملية الإنتاج
وبذللك تحتل المحافظة المركز السادس من حيث الهجرة

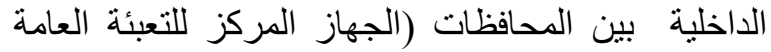

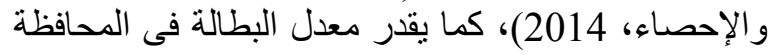

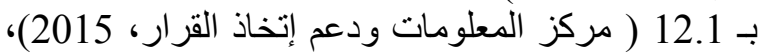

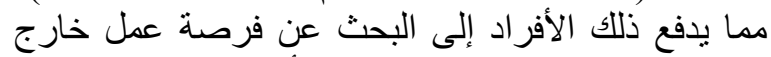

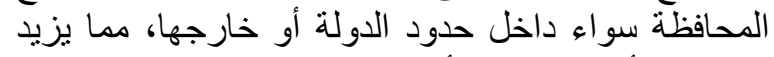

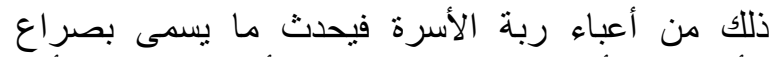

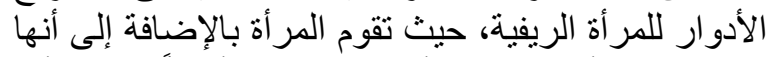

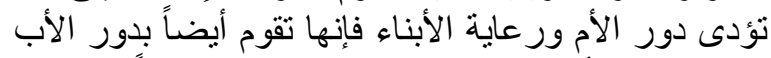

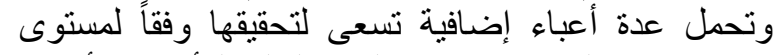

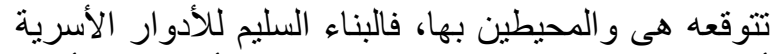
أهم عوامل الحباة الزوجية المستقرة، وقد أصبحت الصبت الأسرة

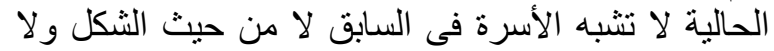

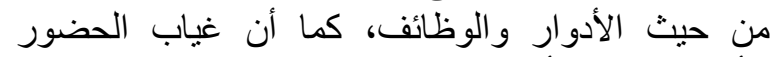

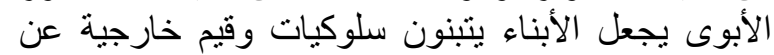

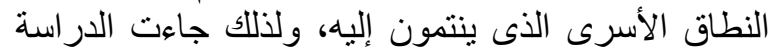

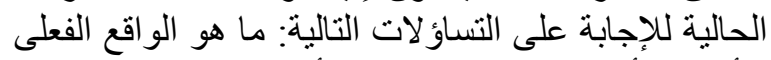

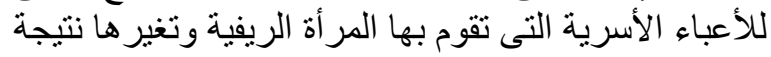

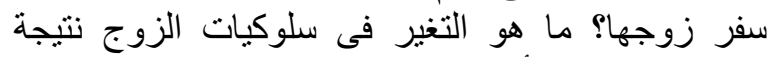

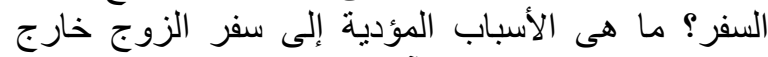

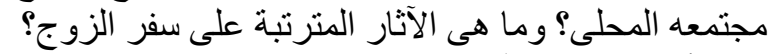

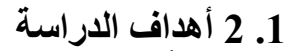
إنساقاً لما ورد فى المشكلة البحثية إستهدفت الدراسة

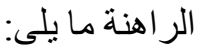
1- الكثف عن الو اقع الفعلى للأعباء الأسرية التى تقوم بها

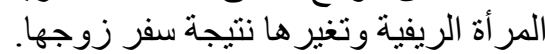

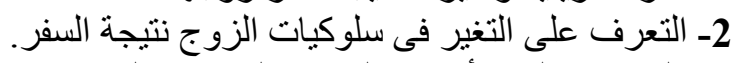

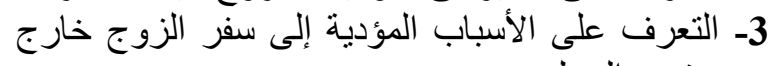
مجتمعه المحلى. 4- تحديد العلاقة بين الأعباء الأسرية للمرأة الريفية قبل

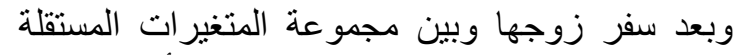

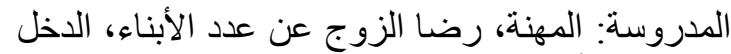

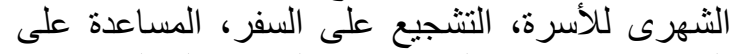

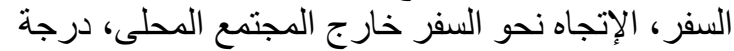
الإنتماء الأسرى، درجة الإتصال الأسرى، درجة العنى العنف درجة

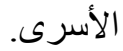
5ـ التعرف على الآثار المترتبة على سفر الزوج.

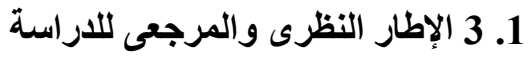
1. 1. 1. 1. مفهوم التغير Change Concept على أنماط العلاقات الإجتماعية فى تنظيم إجنماعى معين

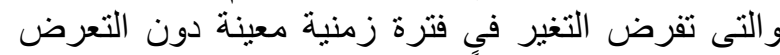

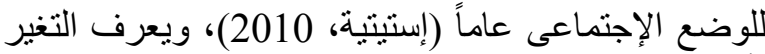
بأنه إختلاف الإنئ عما كان كان عليه خلال فترة محددة من

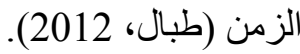

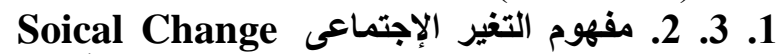

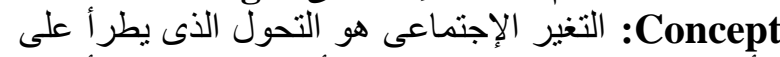

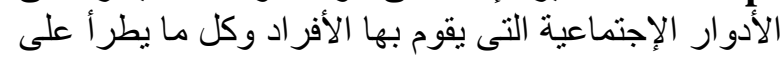

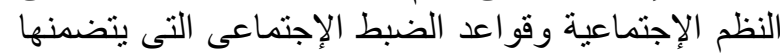

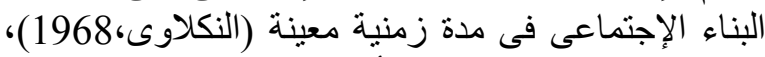

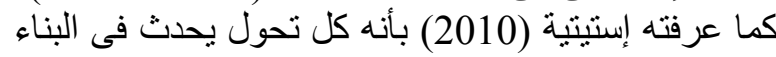


جـ بالنسبة لأثر سفر الزوج على الأبناء: وجود فروق الأبن

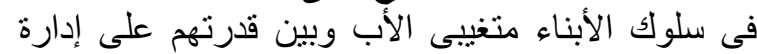

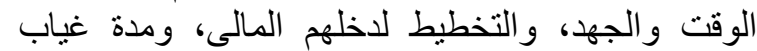

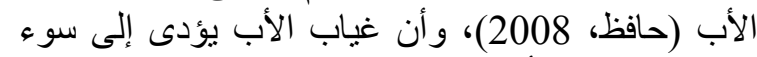
التو افق النفسى للأبناء وتربيتهم ومستوى وان تعليمهم (ميسون الأبون

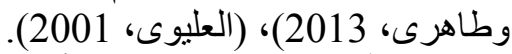

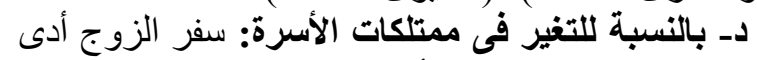

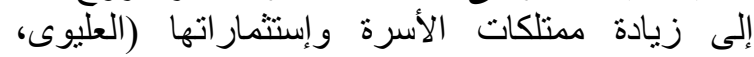
(2001)

هـ - بالنسبة لأسباب السفر: هناك عدة أسباب تدفع

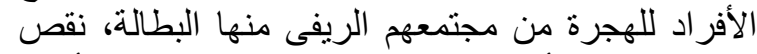

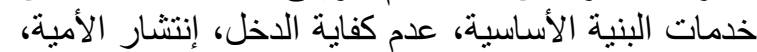

إرتفاع أسعار مستلزمات الإنتاج (أبو سعده، 2015).

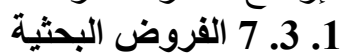

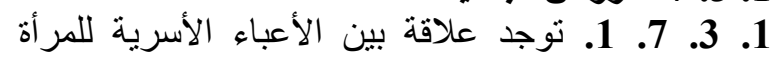

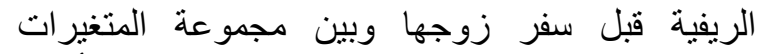

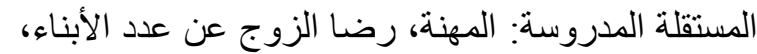

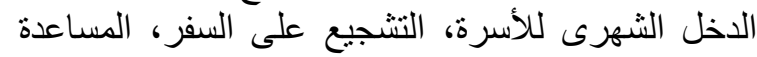

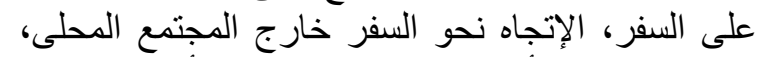
درجة الإنتماء الأسرى، درجة الإتصال الأسرى، درجة الإلى الإلى

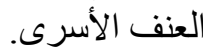

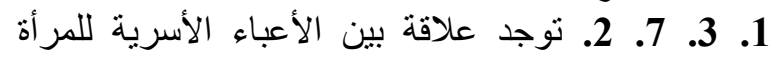

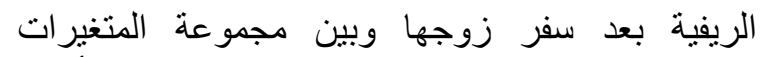

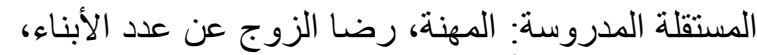

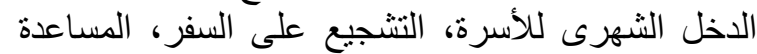

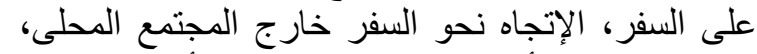

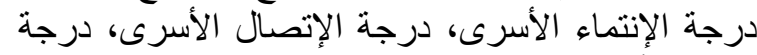

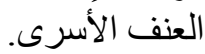

\section{2. منهجية الدراسة و أدواتها}

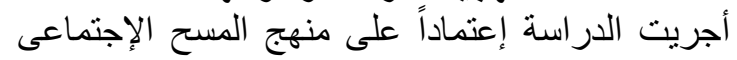

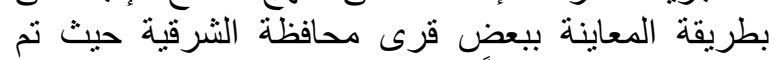
إختيار مركزين وفقاً للمستوى التنموى وذلة وللك بطريقة

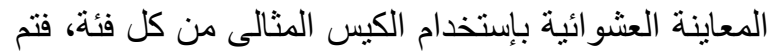

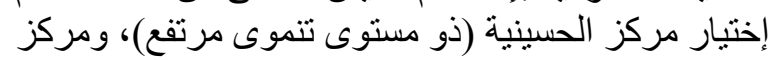

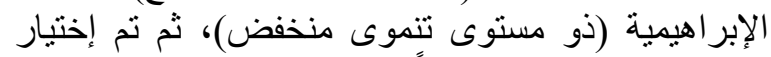

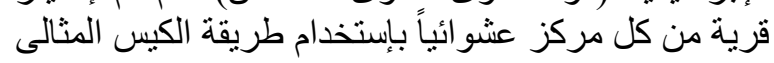

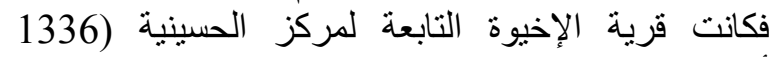

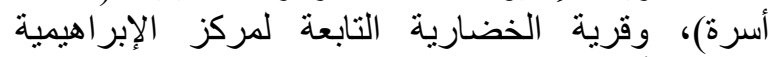

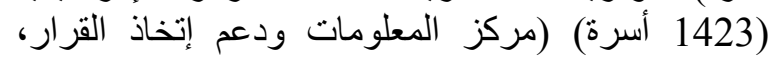

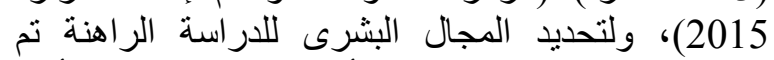

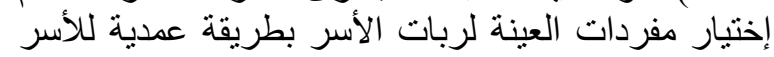

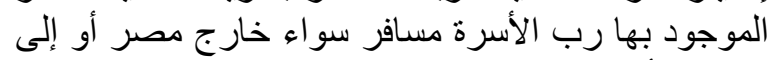
محافظة أخرى داخل حدود الدولة، فبلغ حجم العينة 142

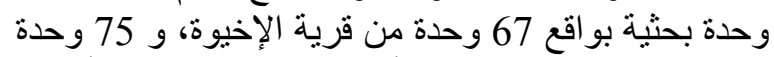

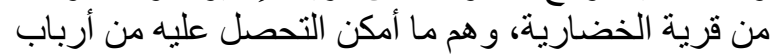

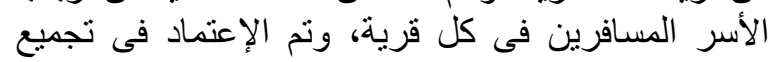

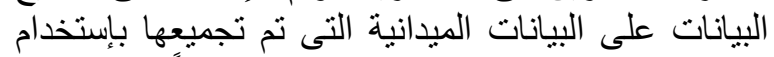

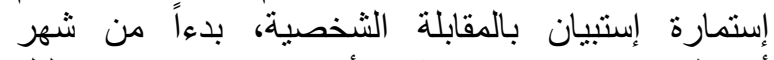
أغسطس وحتى منتصف شهر أكتوبر 2016، وتم تحليل

$$
\text { (فهمى، 2003؛ نفيدسة، 2007). }
$$

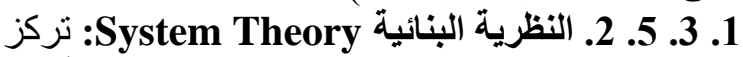

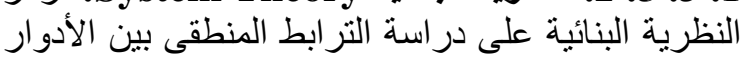

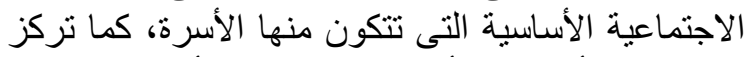

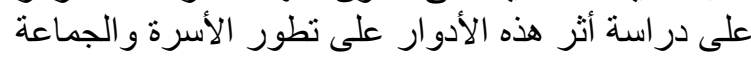

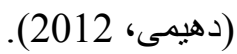

Social 1 Change Theory

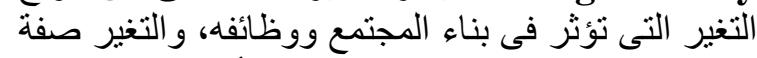

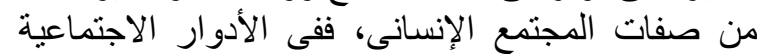

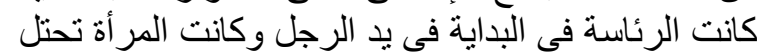

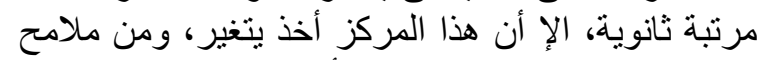

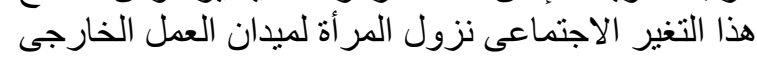

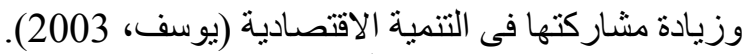

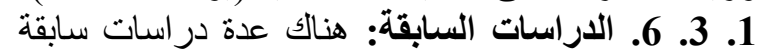

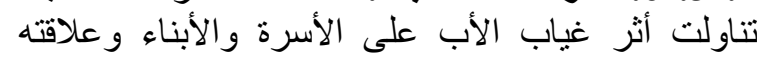

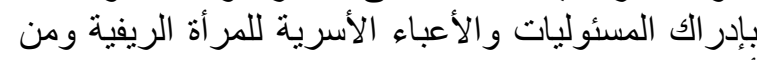

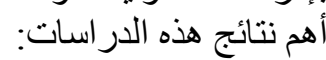
أ- بالنسبة للمشاركة في إنخاذ القرارات بين الزئن الزوجين

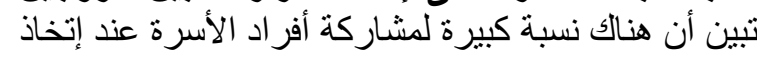

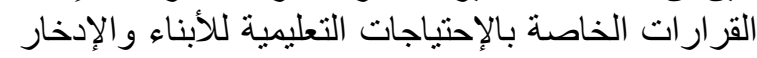

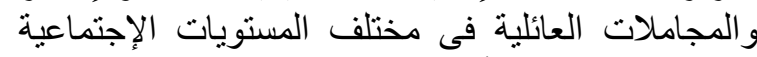

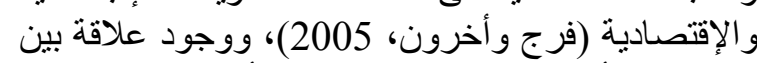
دور ربة الأسرة فى إتخاذ القرارات الخرون الأسرية وبين الدخل

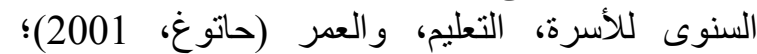

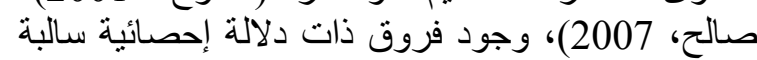

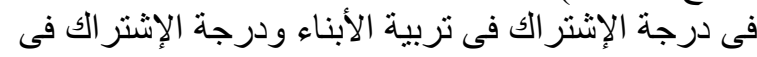

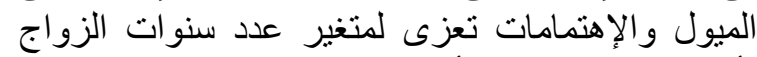

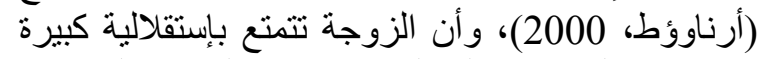

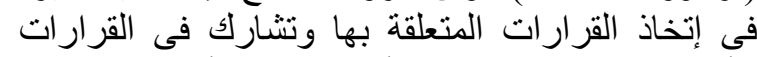

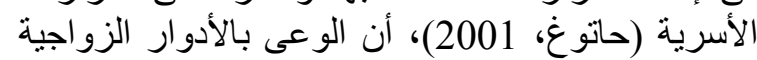

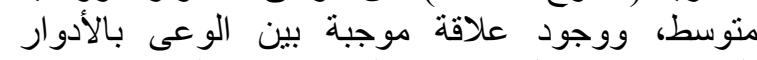

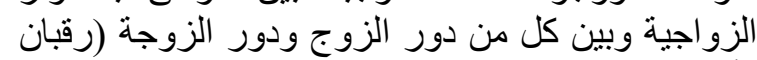

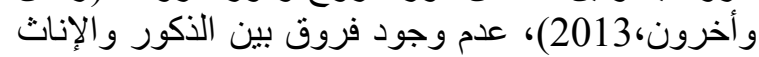

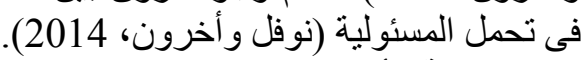

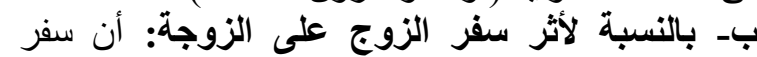

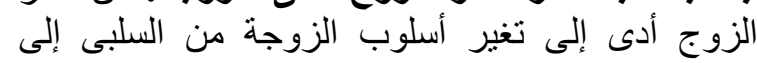

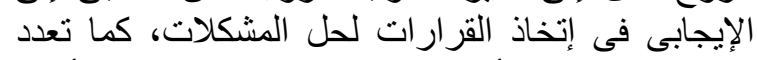

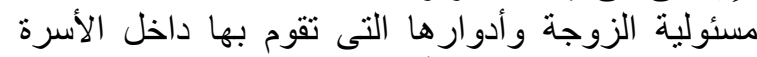

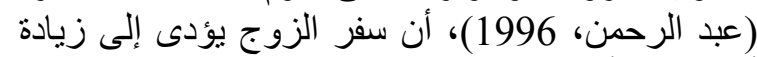

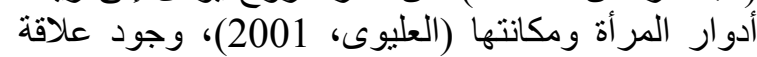

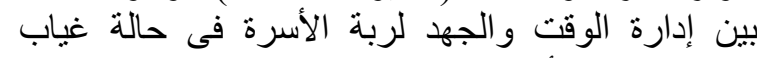

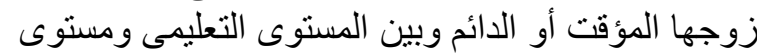

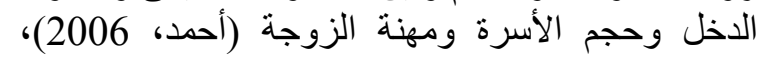

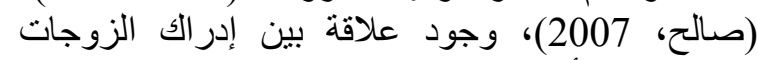

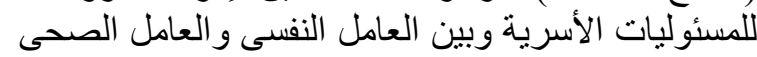

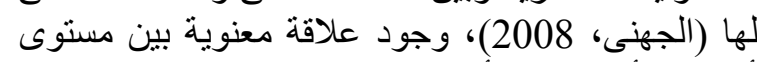
أداء المرأة الريفية لأدو ارها وجئ ودين كل من مستوى معنة الدخل

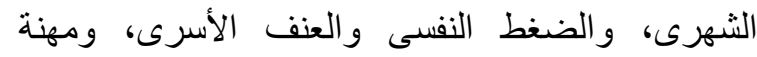
الزوج (الديب وحافظ، 2015). 
للأسرة، ورمزت الإستجابات كالأتى: دائماً=4، أحياناً=3،

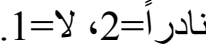

2.2. 2.2. قياس المتغيرات المستقلة المدروسة:

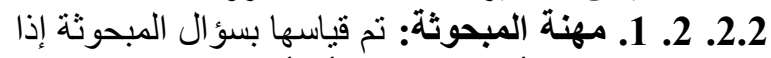

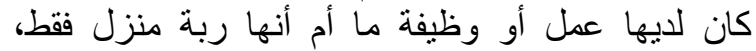

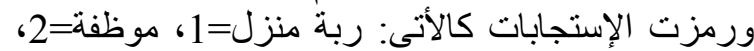
لديها عمل حر= الإسنجايات

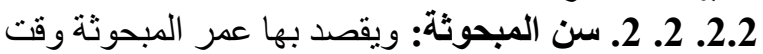
إجر اء الدر اسة، بإستخدام الأرقام المطلقة.

2.2. 2. 3.

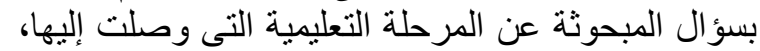

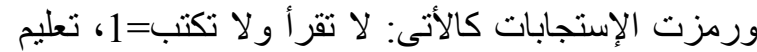

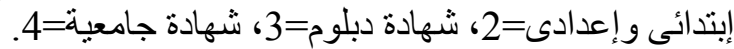

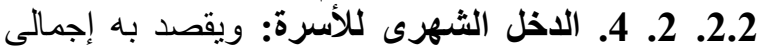
الدخل لأفراد الأسرة فى الثهر ، بإستخدام الأرقام المطلقة.

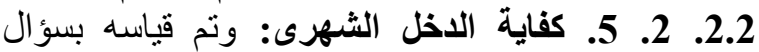

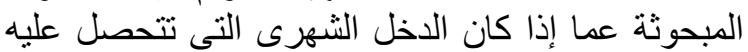

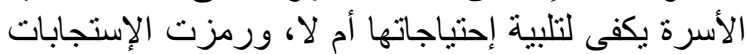

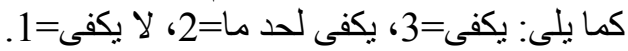

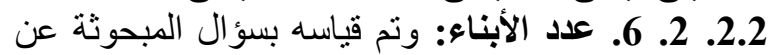
عدد أبنائها وقت إجراء الابناء: الدراسة، بإستخدام الأرقام المطلقة

2.2. 7. 7. رضا الزوج عن عدد الأبناء الحالى: تم قياسه

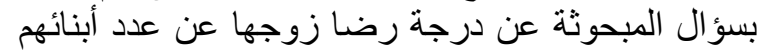

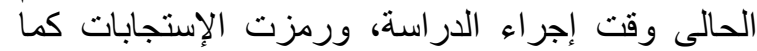

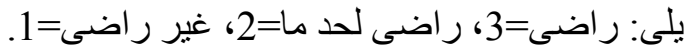

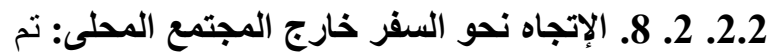

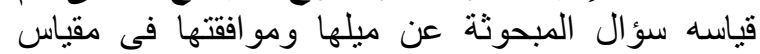

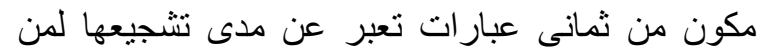

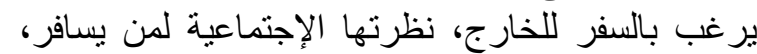

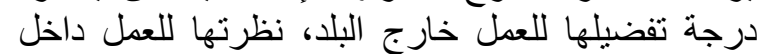

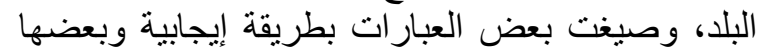

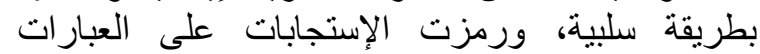

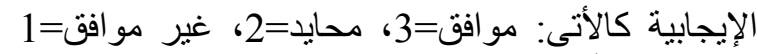

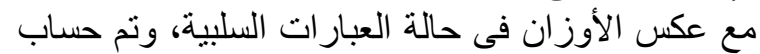
الدرجة الكلية لهذا المتغير بجمع الدالة العبار التات التى حصلت ونت عليها كل مبحوثة.

2.2. 9. 9. الإتجاه نحو الإنتماء الأسرى: تم قياسه بسؤ ال فئال

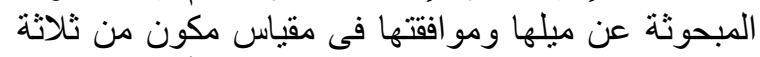

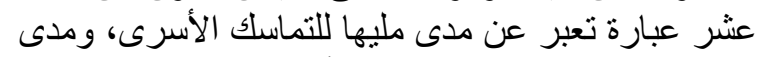

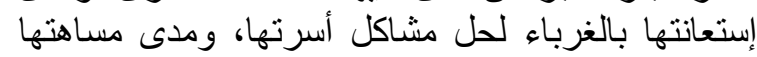

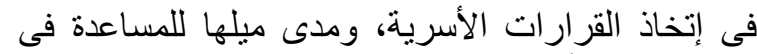

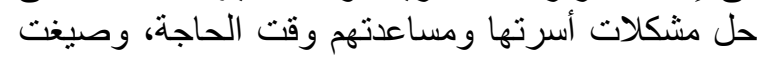
بعض العبارات بطريقة إيجابية وبعضها إنها بطريقة سلبية،

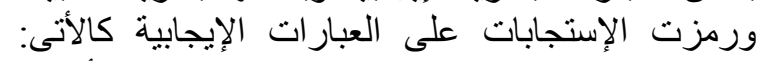

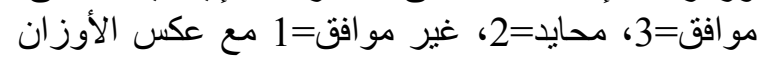

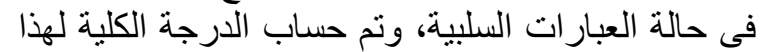

المتغير بجمع الدرجات النى حصلت التئن عليها كل مبحوثنة.

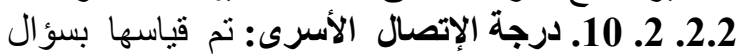

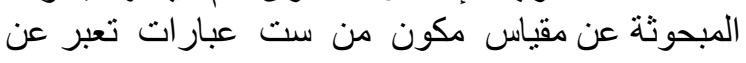

البيانات بإستخدام عدة أساليب إحصائية هى: التكرارات

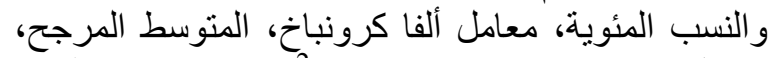

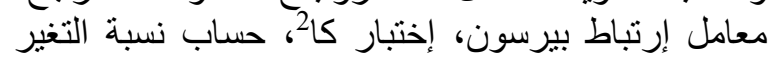
نتيجة السفر من خلال المعادلة التالية:

$$
\text { التغير في السلوك نتيجة السفر = السلوك بعد السفر - السلوك قبل السفر قبل السفر }
$$

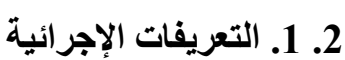

Family Burdens 1.1. مفهوم الأعباء الأسرية الأبراية Concept

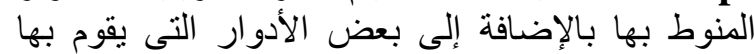
الزوج قبل سفره إلى خار جالى مجتمعه المحلى.

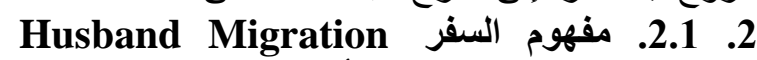
Concept

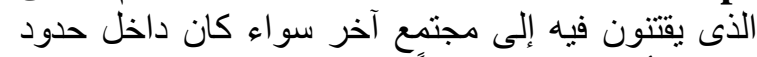
الدولة أو خارجها بحثناً عن عمل لهر لسد إحتياجاتهم ومتطلبات أسر هم.

2.2. قياس المتغيرات البحثية

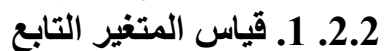

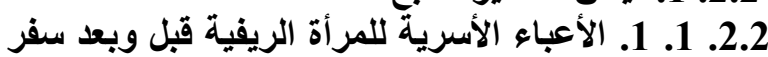

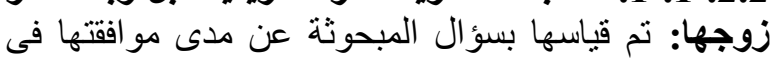

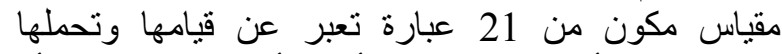

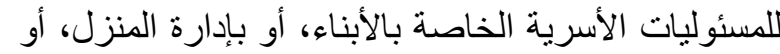

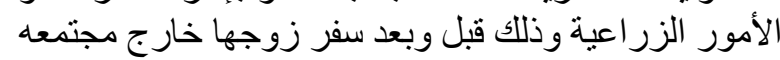

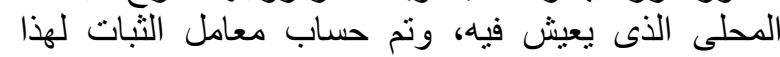

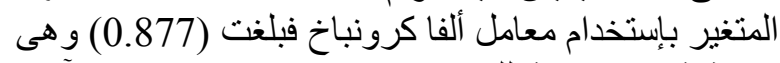

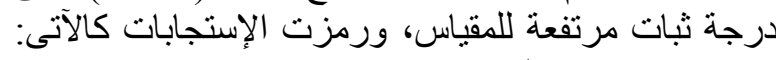

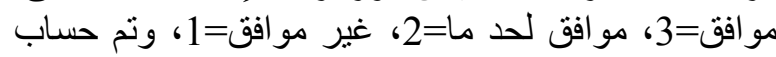

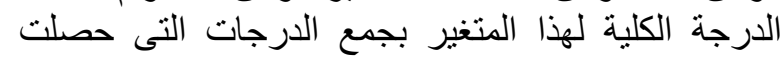
عليها كل مبحوثة.

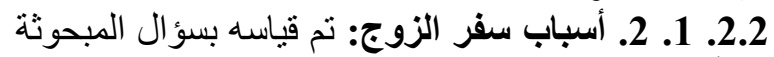

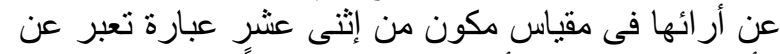

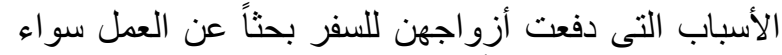

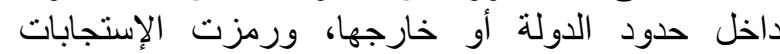

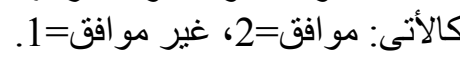

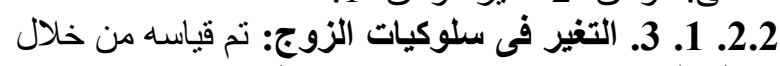

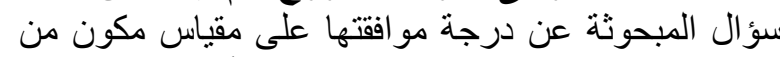

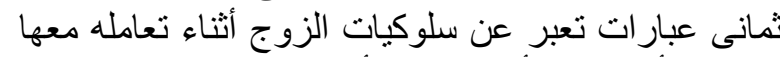

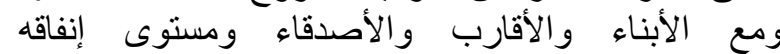

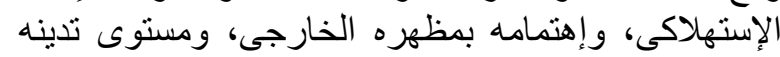

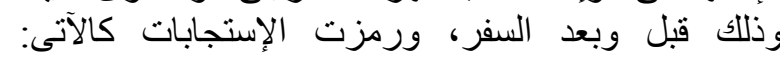

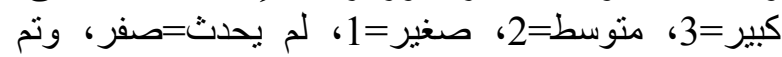

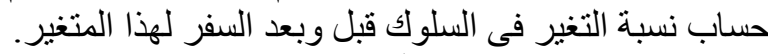

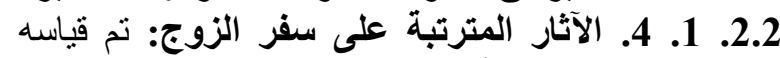

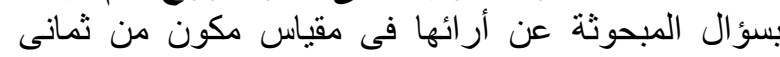

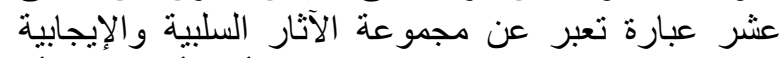

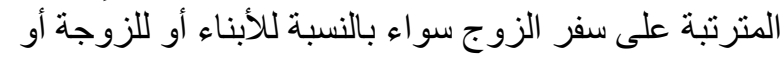




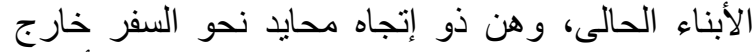

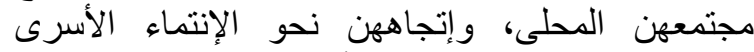

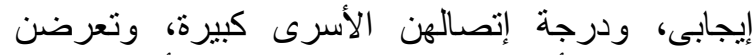

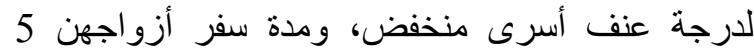

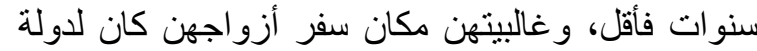

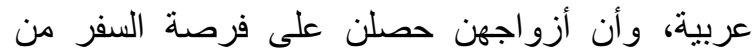

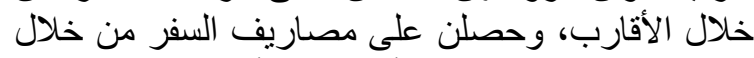

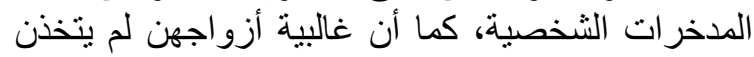
القرار للرجوع إلى مصر والإستقر ار فيها، وكان تقان لقييمهن

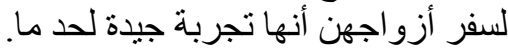

\section{3. النتائج والمناقشة الأشئة}

3. 1. الواقع الفعلى للأعباء الأسرية للمرأة الريفية قبل

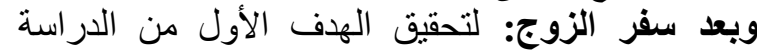

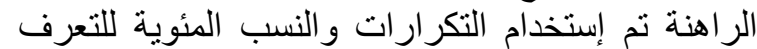

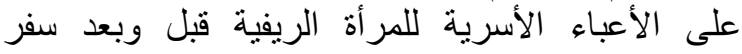
زوجها، بالإضافة إلى حساب نسبة الإبة التغير من خلال إستخدام المنوسط الحسابئ.

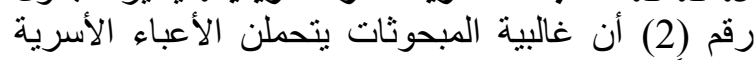

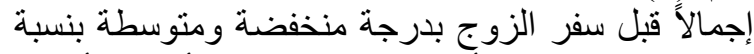

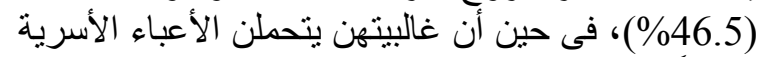

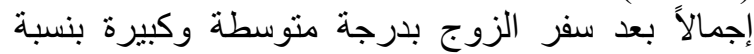

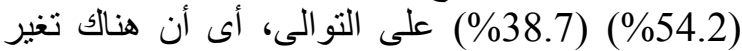
كبير فى الأعباء الأسرية التى تتحملها المرأة الريفية الرئية

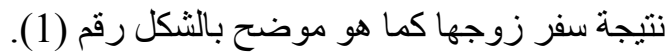

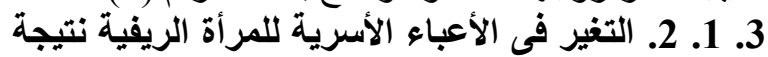

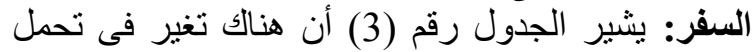

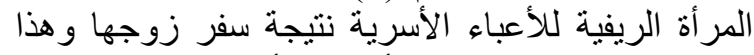

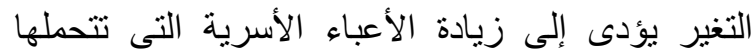

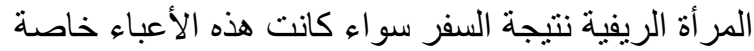
بالأبناء أو الأعباء الإقتصادية أو الأعباء الإجتماعبة أو الواء الزية

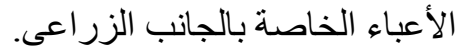

3. 2. الأسباب المؤدية إلى سفر الزئل الزوج خارج مجتمعه

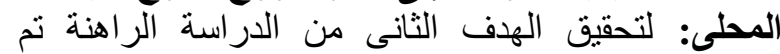

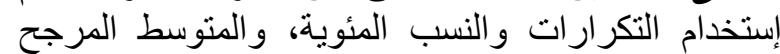
لترتيب هذه الأسباب على حسب أولى النيب النيتها. يشير الجدول رقم (4) إلى الأسباب التى تدفع الريفيين

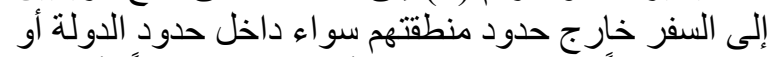

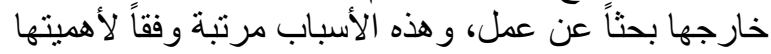

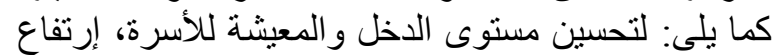

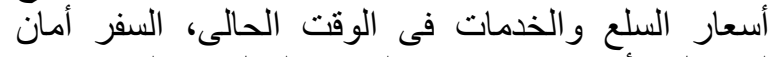

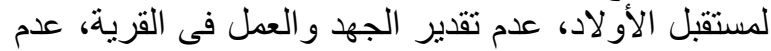

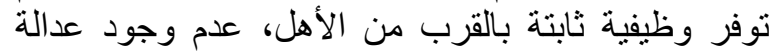

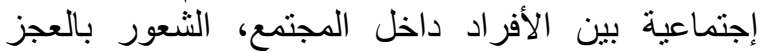

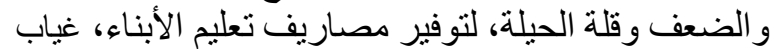

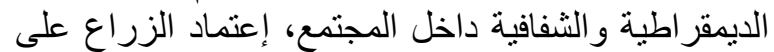

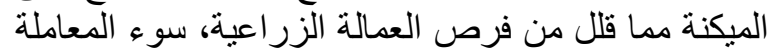

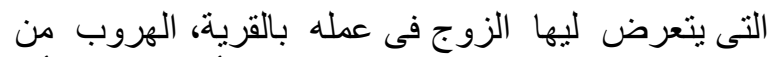
المشاكل العائلية. ومن خلال سرد هذه الأسباب تبين أن الن
درجة الإتصال الأسرى بينها وبين زوجها فى مناقثة

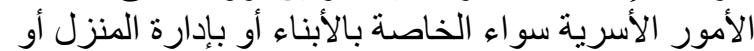

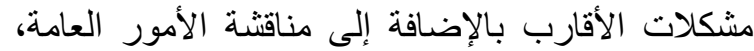

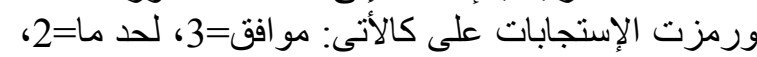

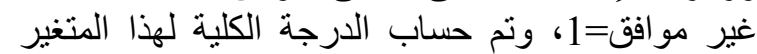
بجمع الدرجات التى حصلت عليها كل مبحوثنة.

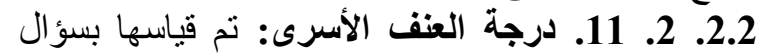

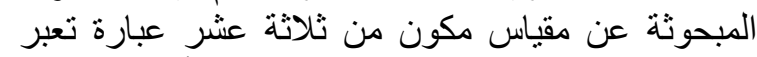

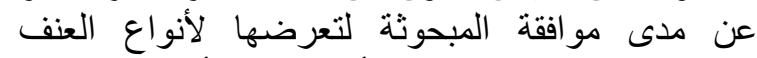

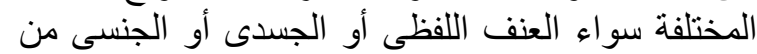

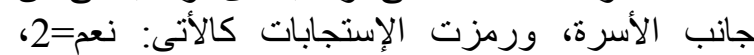

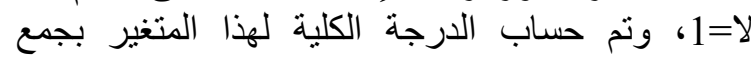

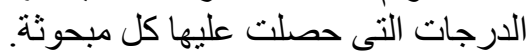

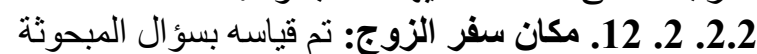

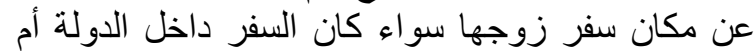

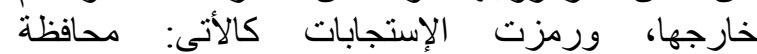

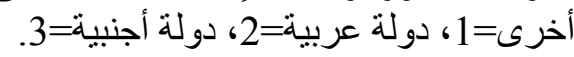

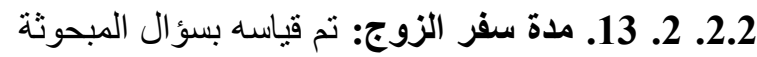

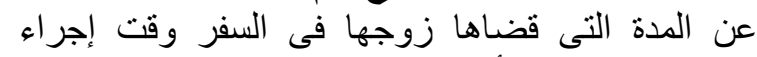
الدر اسة بإستخدام الأرقام المطلقة.

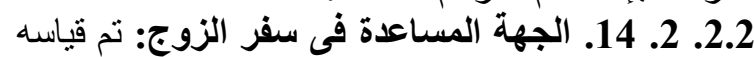

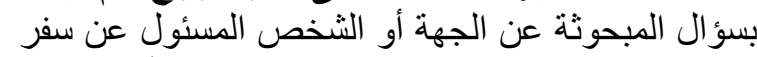

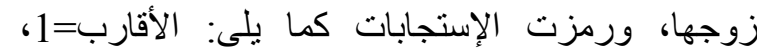

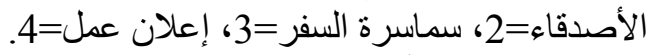

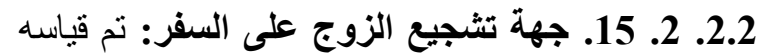

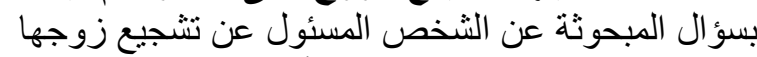

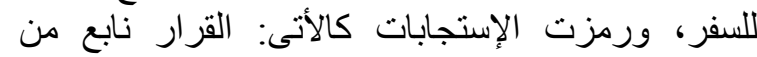

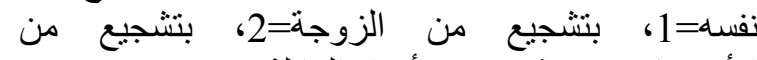
الأصدقاء=3، بتشجيع من أفر اد العائلة=4. 16.

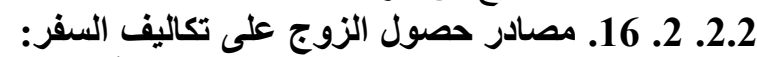

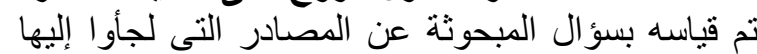

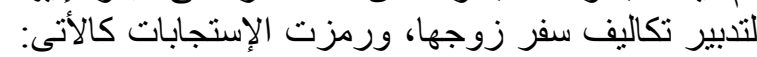

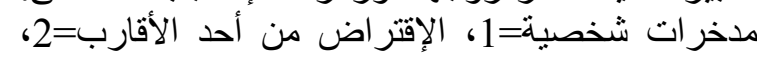
الإقتر اض من الأصدقاء و أهالى القرية=

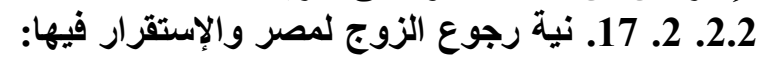

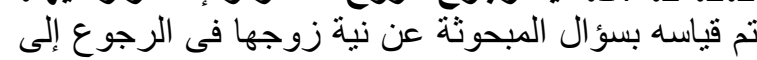

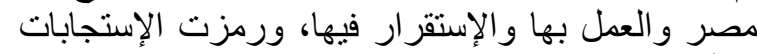

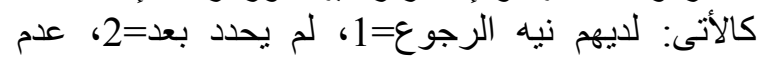

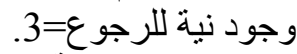

2.2. 2. 18. درجة تقييم المبحوثة لتجربة سفر زوجها:

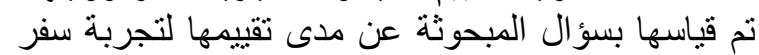

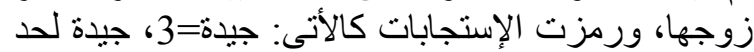
ما=2، سيئة

2.2. 3. خصائص عينة الدراسة: يبين الجدول رقم (1)

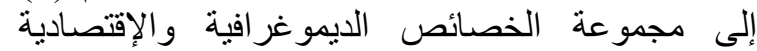

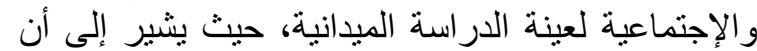

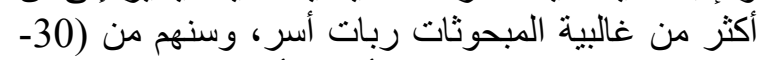

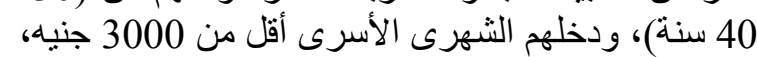

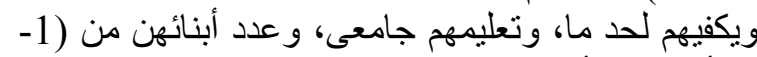

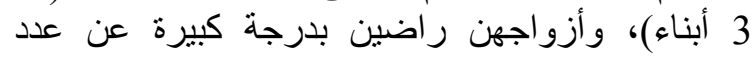


جدول رقم (1): بعض الخصائص الايموغر افية والإقتصادية والإجتماعية لعينة الدراسة.

\begin{tabular}{|c|c|c|c|c|c|c|c|}
\hline$\%$ & العدد & |الفئات & المتغير & $\%$ & العدد & الفئات & المتغير \\
\hline 35.9 & 51 & من (19-29 سنة) & \multirow{3}{*}{ المبحوثة. } & 62 & 88 & ربة منزل & \multirow[t]{3}{*}{ 1-المهنة. } \\
\hline 40.1 & 57 & من (30-40 سنة) & & 34.5 & 49 & موظفة & \\
\hline 23.9 & 34 & من (41-50 سنة) & & 3.5 & 5 & عمل حر & \\
\hline 19 & 27 & لا يكفى & \multirow{3}{*}{ 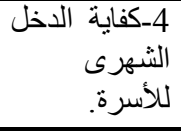 } & 82.4 & 117 & أقل من 3000 جنيه & \multirow{3}{*}{ 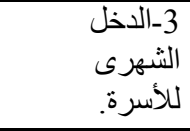 } \\
\hline 56.3 & 80 & يكفى لحد ما & & 14.8 & 21 & من 3000- 6000 جنيه & \\
\hline 24.6 & 35 & يكفى & & 2.8 & 4 & أكبر من 6000 جنيه & \\
\hline 69 & 98 & عدد (1-3 أبناء) & \multirow[t]{3}{*}{ 6-عدد الأبناء. } & 4.9 & 7 & لا تقرأ ولا تكتب & \multirow{4}{*}{ اللتعليمى المستوى } \\
\hline 29.6 & 42 & عدد (4-6 أبناء) & & 9.8 & 14 & تعليم إبتدائى و إعدادى & \\
\hline 1.4 & 2 & عدد (7-9 أبناء) & & 43 & 61 & شهادة دبلوم & \\
\hline 65.5 & 93 & راضى & \multirow{3}{*}{ 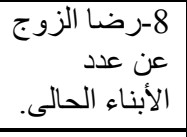 } & 42.3 & 60 & شهادة جامعية & \\
\hline 14.1 & 20 & لحد ما & & 5.6 & 8 & سلبى (من 8-13درجة) & \multirow{3}{*}{ 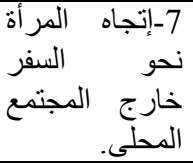 } \\
\hline 20.4 & 29 & غير راضى & & 79.6 & 113 & محايد (من14-19 درجة) & \\
\hline 2.8 & 4 & منخفضة (6-9درجة) & \multirow{3}{*}{ الإسترى. 10 الإلـرجة } & 14.8 & 21 & إيجابى(من 20-24درجة) & \\
\hline 39.4 & 56 & متو سطة(10-14درجة) & & صفر & صفر & سلبى (13-21درجة) & \multirow{3}{*}{ الأإنتماء الإتجاه } \\
\hline 57.7 & 82 & كبيرة (15-18درجة) & & 34.5 & 49 & محايد (22-30درجة) & \\
\hline 62 & 88 & درجة منخفضة(13-16درجة) & \multirow{3}{*}{ الأعنف 12-درجة } & 65.5 & 93 & إيجابى (31-39درجة) & \\
\hline 33.1 & 47 & درجة متوسطة(17-21 درجة) & & 18.3 & 26 & محافظة أخرى & \multirow{3}{*}{ الزوج. 11 } \\
\hline 4.9 & 7 & درجة كبيرة(22-26درجة) & & 77.5 & 110 & دولة عربية & \\
\hline 74.6 & 106 & 5 سنو ات فأقل & \multirow{2}{*}{ الزوج. } & 4.2 & 6 & دولة أجنبية & \\
\hline 25.4 & 36 & أكثر من 5 سنوات & & 45.1 & 64 & القر ار نابع من نفسـه & \multirow{4}{*}{ الزفر. 14-جهة ش شجيع } \\
\hline 38.7 & 55 & الأقارب & \multirow{4}{*}{ سفر الزواعدة الجهة في } & 25.4 & 36 & بتشجيع من الزوجة & \\
\hline 24.6 & 35 & الأصدقاء & & 17.6 & 25 & بتشجيع من الأصدقاء & \\
\hline 29.6 & 42 & سماسرة السفر & & 12 & 17 & بتشجيع من أفراد العائلة & \\
\hline 7.1 & 10 & إعلان عمل & & 67.6 & 96 & مدخر ات شخصية & \multirow{3}{*}{ 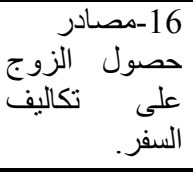 } \\
\hline 29.6 & 42 & للديهم نيه الرجوع & \multirow{3}{*}{ 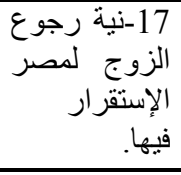 } & 22.5 & 32 & الإقتر اض من أحد الأقَارب & \\
\hline 60.6 & 86 & لم يحدد بعد & & 9.9 & 14 & وأهالى القرية من الأصدقاء & \\
\hline 9.8 & 14 & عدم وجود نية للرجوع & & 5.6 & 8 & سيئة & \multirow{3}{*}{ 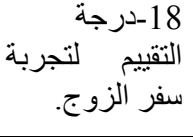 } \\
\hline \multirow{2}{*}{\multicolumn{4}{|c|}{ 142=ن }} & 66.9 & 95 & جيدة لحد ما & \\
\hline & & & & 27.5 & 39 & جيدة & \\
\hline
\end{tabular}

جدول رقم (2): الأعباء الأسرية للمرأة الريفية قبل وبعد سفر الزوج.

\begin{tabular}{|c|c|c|c|c|}
\hline \multicolumn{2}{|c|}{ الأعباء الأسرية للمر أة الريفية بعد السفر } & \multicolumn{2}{|c|}{ الأعباء الأسرية للمر أة الريفية قبل السفر } & \multirow{2}{*}{ 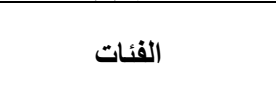 } \\
\hline$\%$ & 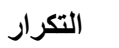 & $\%$ & 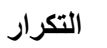 & \\
\hline 7 & 10 & 46.5 & 66 & منخفضة(21-34 درجة) \\
\hline 54.2 & 77 & 46.5 & 66 & متوسطة(35-49درجة) \\
\hline 38.7 & 55 & 7 & 10 & مرتفعة(50-63درجة) \\
\hline
\end{tabular}

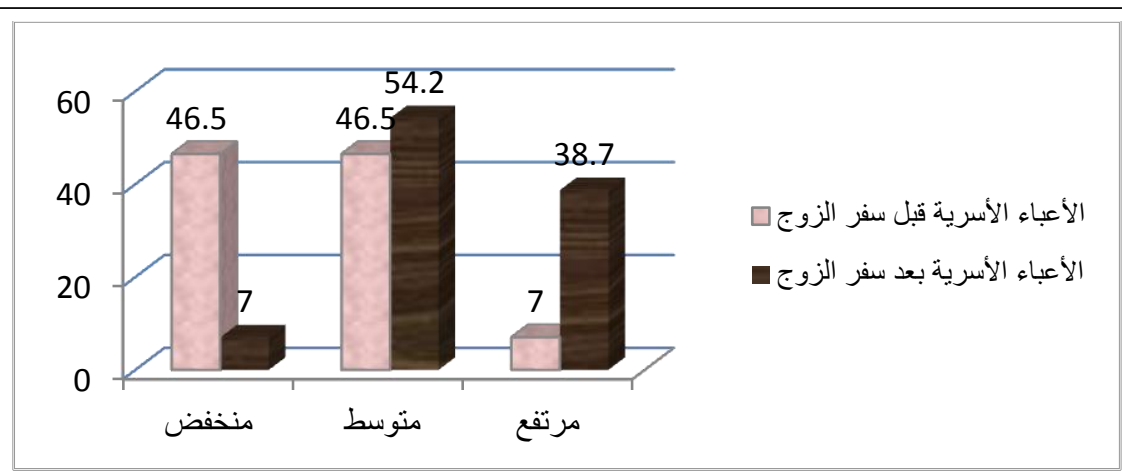

شكل رقم (1): الأعباء الأسرية للمرأة الريفية قبل ويعد سفر الزوج. 
جدول رقم (3): التغير فى الأعباء الأسرية للمرأة الريفية نتيجة سفر الزوج مرتبة ترتيباًتنازلياً.

\begin{tabular}{|c|c|c|c|}
\hline التغير (\%) & متوسط الأعباء بعد & متوسط الأعباء قبل & الأعباء \\
\hline \multicolumn{4}{|r|}{ أولأ: الأعباء الخاصة بالأبناء: } \\
\hline 67.08 & 2.64 & 1.58 & 1-لجوء الأبناء فى المشورة و النصيحة لحل مشكلاتهم. \\
\hline 56.41 & 2.44 & 1.56 & 2-توجيه الأبناء عند التأخير. \\
\hline 41.97 & 2.30 & 1.62 & 3- معاقبة الأبناء عند الخطأ. \\
\hline 35.29 & 2.76 & 2.04 & 4-متابعة الأبناء فى المدارس. \\
\hline 26.47 & 2.15 & 1.70 & 5-مكافأة الأبناء عند الإثابة. \\
\hline 25.52 & 2.41 & 1.92 & 6-شر اء ملابس الأبناء. \\
\hline 16.66 & 2.73 & 2.34 & 7-متابعة الرعاية الصحية للأبناء. \\
\hline 15.51 & 2.83 & 2.45 & 8-مباشرة الأبناء فى المذاكرة. \\
\hline \multicolumn{4}{|r|}{ ثانياً: الأعباء الاقتصادية: } \\
\hline 55.71 & 2.18 & 1.40 & 1- شر اء أصول وممتلكات جديدة. \\
\hline 34.82 & 2.71 & 2.01 & 2-إدارة مصروف البيت. \\
\hline & & & ثُالثًا: الأعباء الإجتماعية: \\
\hline 35.46 & 2.33 & 1.72 & 1-إتخاذ القرارات المتعلقة بالتعليح. \\
\hline 30.15 & 2.46 & 1.89 & 2- الزيار ات و الصداقات الأجتماعية. \\
\hline 28.91 & 2.14 & 1.66 & 3- إتخاذ القرار ات الأسرية. \\
\hline \multicolumn{4}{|r|}{ رابعاً: الأعباء الخاصةٌ بالجانب الزراعى: } \\
\hline 44.44 & 1.95 & 1.35 & 1-عمليات العناية بالأرض الزر اعية. \\
\hline 44.11 & 1.96 & 1.36 & 2-الإتفاق مع العمالة المستأجرة. \\
\hline 39.43 & 1.98 & 1.42 & 3-زر اعة الآرض. \\
\hline 39.41 & 1.91 & 1.37 & 4-التعامل مع المنظمات الخدمية الزر اعية بالقرية كالجمعية التعاونية. \\
\hline 33.07 & 1.73 & 1.30 & 5-إختيار نوعية المحاصيل المنزر عة. \\
\hline 27.56 & 1.99 & 1.56 & 6-بيع المنتجات الزر اعية. \\
\hline 22.48 & 2.07 & 1.69 & 7-العناية بالحيو انات المزر عية. \\
\hline 18.23 & 2.14 & 1.81 & 8-حليب الحيو انات المزرعية. \\
\hline 33.62 & 47.89 & 35.84 & الارجة الإجمالية للأعباء الأسرية. \\
\hline
\end{tabular}

جدول رقم (4): الأسباب التى تدفع الريفيين إلى السفر.

\begin{tabular}{|c|c|c|c|c|c|c|}
\hline \multirow{2}{*}{ الترتيب } & \multirow{2}{*}{ 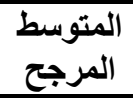 } & \multicolumn{2}{|c|}{ غيز موافق } & \multicolumn{2}{|c|}{ موافق } & \multirow{2}{*}{ الأسباب } \\
\hline & & $\%$ & العدد & $\%$ & العدد & \\
\hline الأول & 94 & 1.4 & 2 & 98.6 & 140 & 1- لتحسين مستوى الدخل و المعيشة للأسرة. \\
\hline الثانى & 90.6 & 8.5 & 12 & 91.5 & 130 & 2- إرتفاع أسعار السلع و الخدمات فى الوقت الحالى. \\
\hline الثالث & 90 & 9.9 & 14 & 90.1 & 128 & 3- أمان لمستقبل الأو لاد. \\
\hline 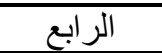 & 86.3 & 17.6 & 25 & 82.4 & 117 & 4- عدم تقدير الجهـ و العمل فى القرية. \\
\hline 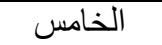 & 86 & 18.3 & 26 & 81.7 & 116 & 5- عدم توفر وظيفية ثابتة بجانب الأهل. \\
\hline السادس & 84.6 & 21.1 & 30 & 78.9 & 112 & 6- عدم وجود عدالة إجتماعية بين الأفر اد داخل المجتمع. \\
\hline السابع & 82.3 & 26.1 & 37 & 73.9 & 105 & 7- الثعور بالعجز و الضعف وقلة الحيلة. \\
\hline الثامن & 79.6 & 31.7 & 45 & 68.3 & 97 & 8- توفير تكاليف تعليم الأبناء. \\
\hline 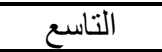 & 76.6 & 38 & 54 & 62 & 88 & 9- غياب الديموقر اطية و الثفافية داخل المجتمع. \\
\hline العاشر & 76 & 39.4 & 56 & 60.6 & 86 & 10- إعتماد الزر اع على الميكنة مما قلل من فرص العمالة \\
\hline الحادى عشر & 75.3 & 40.8 & 58 & 59.2 & 84 & 11- سو المعاملة اللى إتعرض ليها الزوج فى عمله بالقرية. \\
\hline الثانى عشر & 66.3 & 59.9 & 85 & 40.1 & 57 & 12- الهروب من المشاكل العائلية. \\
\hline
\end{tabular}




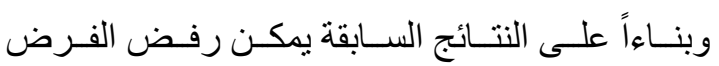

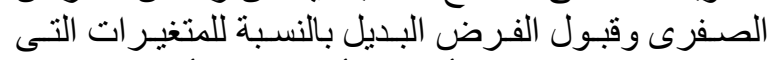

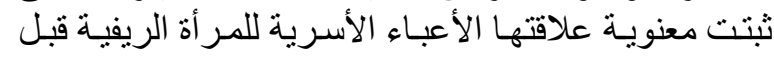

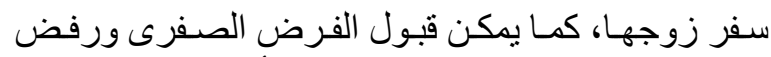

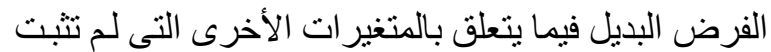
معنوية علاقتها.

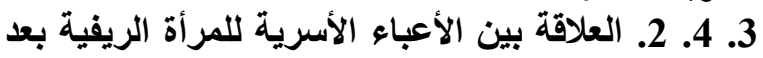

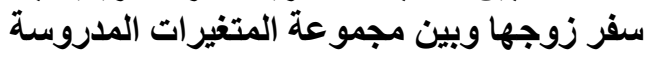

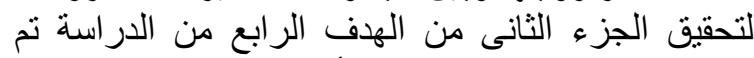

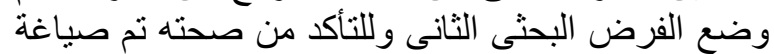
الفرض الصفرى التالى "لانى توجد علاقلة بين الأعباء

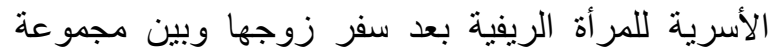

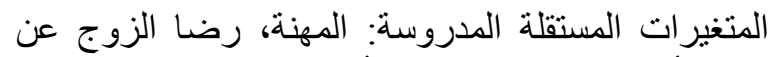

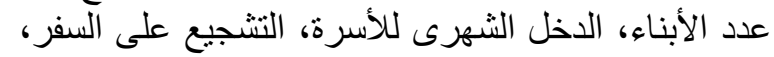

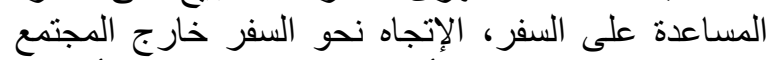

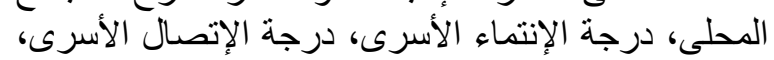
درجة العنف الأسرى"، ولإختبار هذه الفرض الإن تم إستخدام معامل إرتباط بيرسون للمتغيرات ذإنة ذات الطبيرة الطبيعة الكمية،

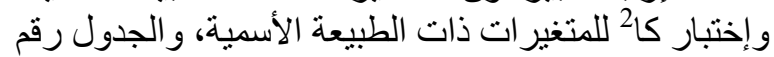
(6) يوضح ذلك. 3 يشير الجدول رقم (6) لوجود علاقة إرتباطية سالبة بين

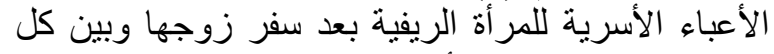

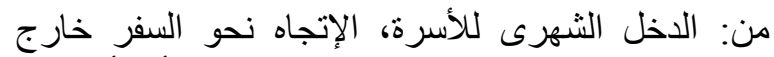

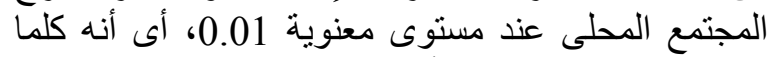
إنخفض الدخل الشهرى لأسرة المبحوثنة و إنخفض معند إتجاهيا

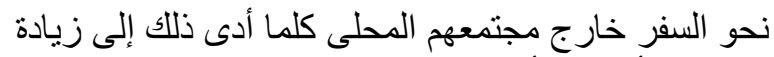

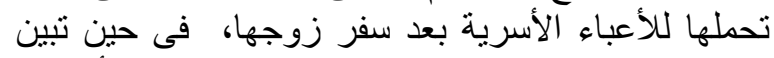

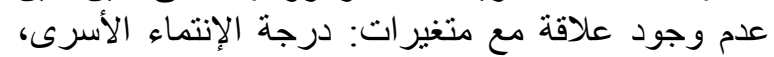

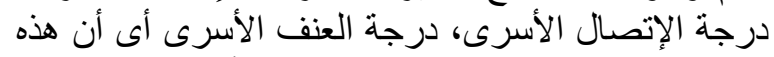

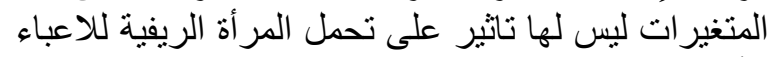

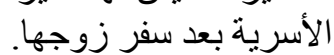

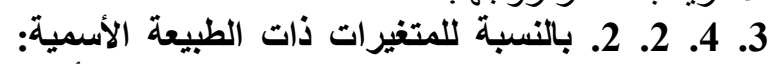
يشير الجدول رقم (6) لوجود علاقة إقتر انية بين الأعباء

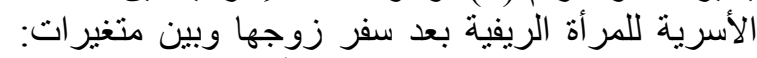

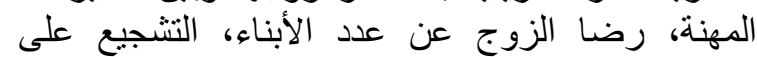
السفر، المساعدة على السفر عند مستوى معنوية 0.05.

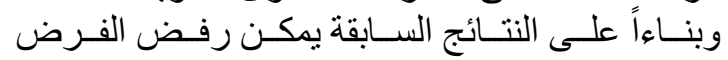

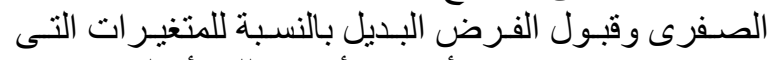

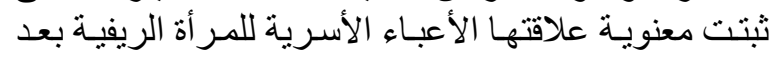

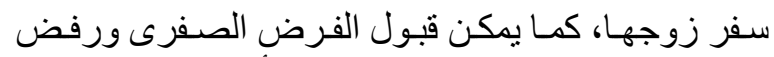

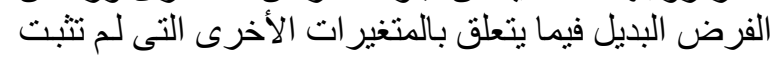
معنوية علاقتها.

3. 5. الآثار المترتبة على سفر الزوج خارج مجتمعه

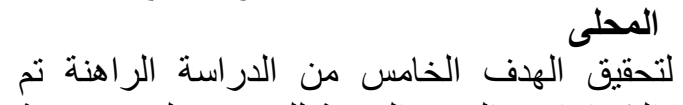

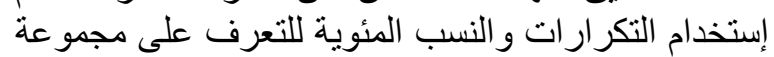

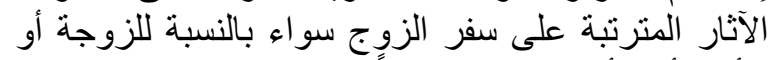
للأبناء أو للأسرة وترتئهار على وفقاً للمتوسط المرجح.
أهم الأسباب التى تدفع الريفيين للسفر هو العامل

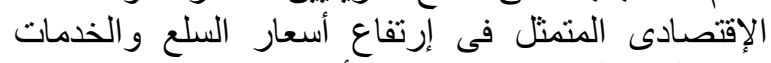

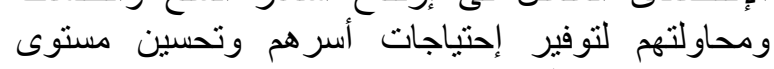
معيثتهم من خلال سفر هم.

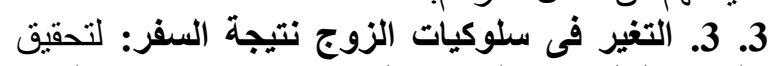

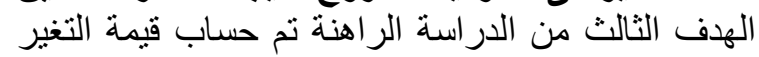

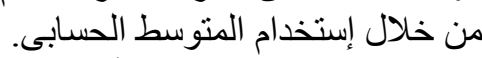

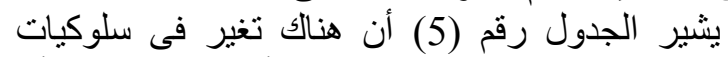

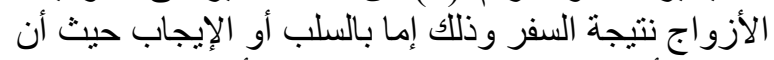

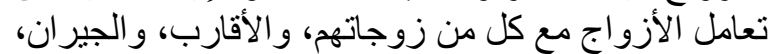

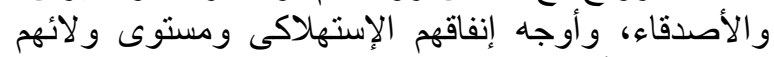

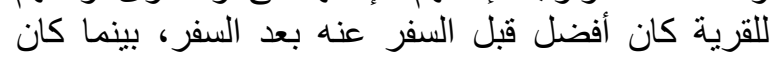

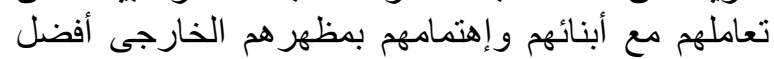

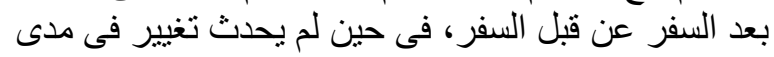
3. 4. العلاقة بينة السفر. الأعباء الأسرية للمر أة الريفية قبل وبعد

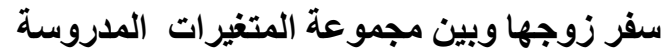

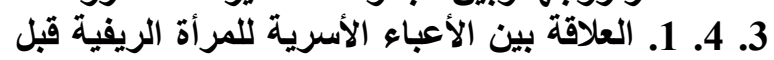

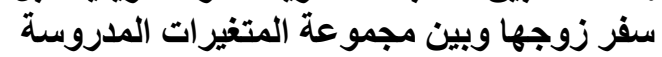

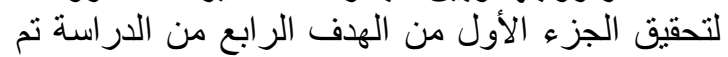

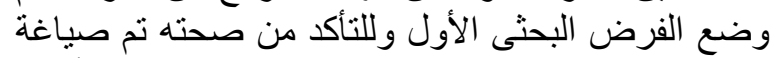
الفرض الصفرى التالى "لا توجد علاقة لإول بين الأعباء

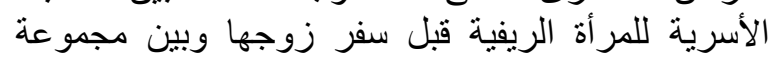

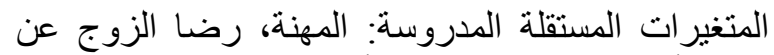

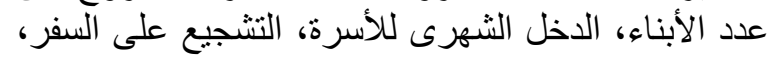

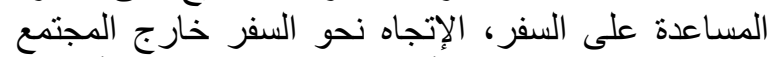

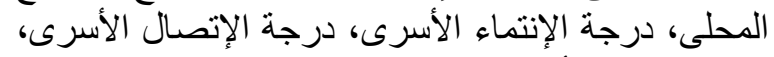
درجة العنف الأسرى"، ولإختبار هذه الفرض تم إلماء إستخدام

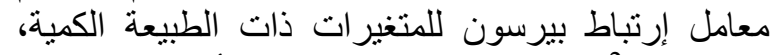

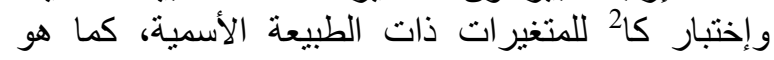
موضح بالجدول رقم (6) 3. 4. 1. 1. بالنسبة للمتغيرات ذات الطبيعة الكمية: يشير

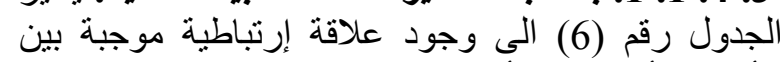

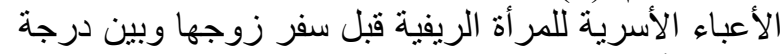
العنف الأسرى، و علاقة إرتباطبة سالبة مع كل من: الإتجاه

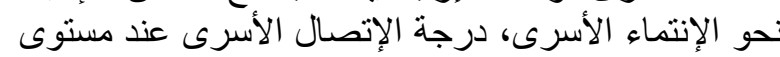

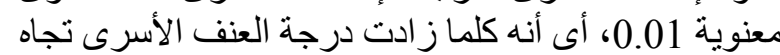

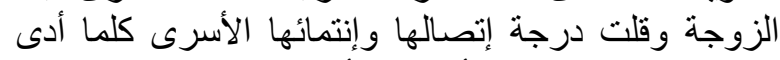

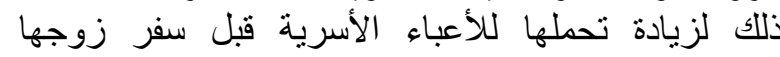
بمفردها، وفى حين تبين عدم وجود علاقة مع متغيراء الات

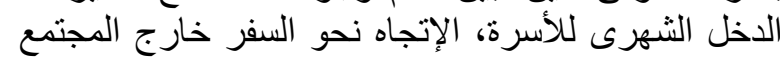

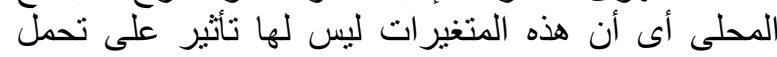

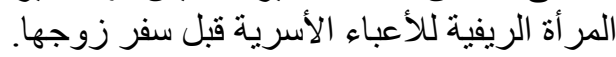
3. 4. 1. 2.

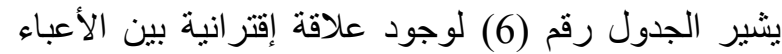

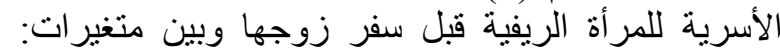

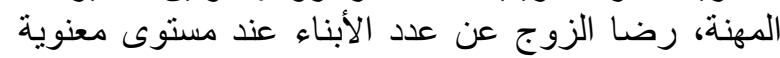
0.05، فى حين تبين عدم وجود علاقة عدة مع متغيرات: التشجيع على السفر، المساعدة على السفر. 
H. A.A. El-Deeb and S. M. Sh. Newaser ...........................................................

جدول رقم (5): التغير في سلوكيات الزوج نتيجة السفر.

\begin{tabular}{|c|c|c|c|}
\hline التغير(\%) & المتوسط بعد السفر & المتوسط قبل السفر & السلوكيات \\
\hline $6.87-$ & 1.49 & 1.60 & 1-أسلوب التعامل مع الزوجة. \\
\hline 4.05 & 1.54 & 1.48 & 2-أسلوب التعامل مع الأبناء. \\
\hline $7.62-$ & 1.09 & 1.18 & 3-أسلوب التعامل مع الأقارب. \\
\hline 10.61- & 1.01 & 1.13 & 4-أسلوب التعامل مع الجيران. \\
\hline $3.30-$ & 1.17 & 1.21 & 5-أسلوب التعامل مع الأصدقاء. \\
\hline $2.25-$ & 1.30 & 1.33 & 6-أوجه الإنفاق الإستهلاكى. \\
\hline صفر & 1.61 & 1.61 & 7-مستوى التدين. \\
\hline 5.46 & 1.35 & 1.28 & 8-الإهتمام بالمظهر الخارجى \\
\hline 8.33- & 0.88 & 0.96 & 9-مستوى الو لاء للقرية. \\
\hline
\end{tabular}

جدول رقم (6): العلاقة بين الأعباء الأسرية للمر أة الريفية قبل وبعد سفر زوجها وبين مجموعة المتغيرات المدروسة.

\begin{tabular}{|c|c|c|c|c|}
\hline \multicolumn{2}{|c|}{ الأعباء الأسرية بعد سفر الزوج } & \multicolumn{2}{|c|}{ الأعباء الأسرية قبل سفر الزوج } & \multirow[t]{2}{*}{ ال المتغير } \\
\hline قيمة كا2 & قيمة معامل بيرسون & قيمة كا2 & قيمة معامل بيرسون & \\
\hline$* 12.129$ & - & $* 11.495$ & - & 1- 1المهنة. \\
\hline$* 11.440$ & - & $* 12.811$ & - & 2-رضا الزوج عن عدد الأبناء \\
\hline- & $* * 0.231-$ & - & $0.030-$ & 3-الدخل الثهرى للأسرة. \\
\hline$* 15.784$ & - & 8.429 & - & 4-التشجيع على السفر . \\
\hline$* 35.382$ & - & - & 10.448 & 5-المساعدة على السفر. \\
\hline- & $* * 0.244$ & - & 0.104 & 6-الإتجاه نحو السفر خارج المجتمع المحلى. \\
\hline- & 0.029 & - & $* * 0.384$ & 7-درجة الإنتماء الأسرى. \\
\hline- & 0.005 & - & $* * 0.254$ & 8-درجة الإتصال الأسرى. \\
\hline- & $0.081-$ & - & $* * 0.228$ & 9-درجة العنف الأسرى. \\
\hline & ن & كية 0.010 & |** مستوى & |* مستوى معنو \\
\hline
\end{tabular}

العمرة، عمل مشروع صغير لتأمين أفراد الأسرة، مساعدة بعض الأقارب في السفر. 3. 6. بـ التوصيات بناءاً على ما توصلت إليه الدراسة من نتائج توصى

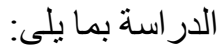
3. 1. 1. يجب على الآباء والأمهات أن يقوموا بالإتفاق على قواعد للسلوك الذى يمكن إنتهاجه مع الأبناء الأبناء

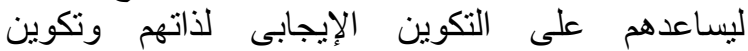
شخصياتهم.

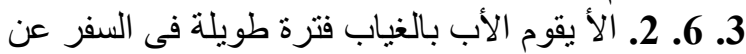

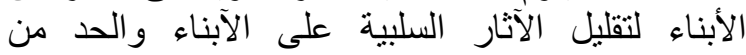

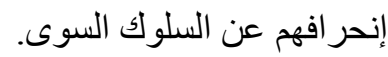

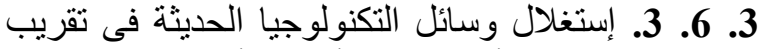
المسافات بين رب الأسرة وباقى أفر اد الأسرة لخلق جو من لفن فئ التفاعل المنو اصل و والمستمر بينهم. 3. 6. 4. العمل على زيادة الإتصال بين أفر اد الأسرة الكبيرة

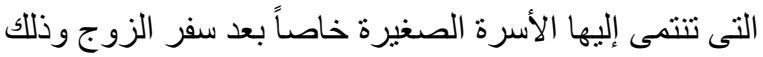

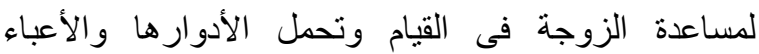
ومسئوليات الأسرية التى زادت عليها نتيجة سفر الزوج.
يوضح الجدول رقم (7) مجموعة الآثار المنرنبة على إلى إلى

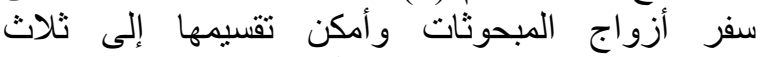
مجموعات رئيسية، وهذه الآثار مرنبة على الثى حسب التى

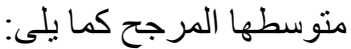
3. 5. 1. الآثار بالنسبة للزوجة: لزئة زيادة الخلافات العائلية

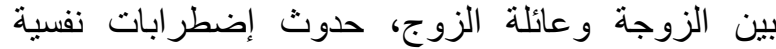
للزوجة نتيجة الضغط وزيادة التئة تحمل المسئولية بمفردها،

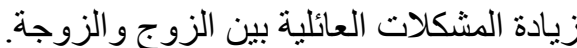

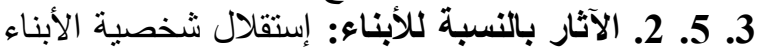

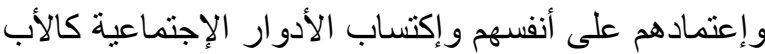

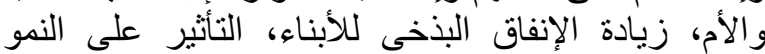

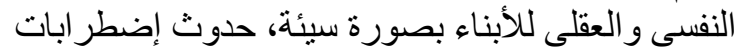

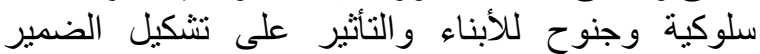

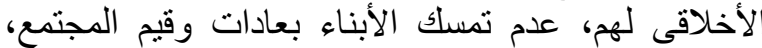

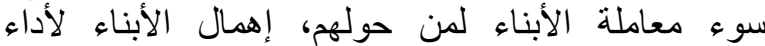

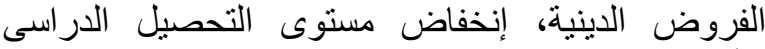
للأبناء. 3. 5. 3. الآثار بالنسبة للأسرة: زيادة دخل الأسرة

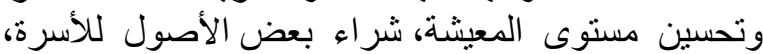

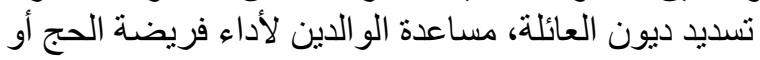


جدول رقم (7): الآثار المترتبة على سفر الزوج.

\begin{tabular}{|c|c|c|c|c|c|c|c|c|c|c|}
\hline \multirow{2}{*}{ الترتيب } & \multirow{2}{*}{ المتوسط } & \multicolumn{2}{|c|}{ 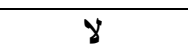 } & \multicolumn{2}{|c|}{ نادراً } & \multicolumn{2}{|c|}{ أحياناً } & \multicolumn{2}{|c|}{ دائما } & \multirow{2}{*}{ الآثار } \\
\hline & & $\%$ & العدد & $\%$ & العدد & $\%$ & العدد & $\%$ & العدد & \\
\hline & & & & & & & & & & أـ الآثار بالنسبة للزوجة: \\
\hline الأول & 38.6 & 10.6 & 15 & 28.9 & 41 & 38.7 & 55 & 21.8 & 31 & 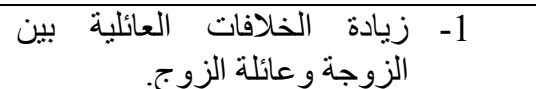 \\
\hline الثانى & 37.1 & 14.8 & 21 & 27.5 & 39 & 39.4 & 56 & 18.3 & 26 & 2-حدوث إضطر و وزيادة تحملة للزوجة المسئولية \\
\hline 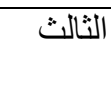 & 33.8 & 23.2 & 33 & 30.3 & 43 & 31.7 & 45 & 14.8 & 21 & 3-زيادة المشكلات العائلية بين الزوج \\
\hline الر ابع & 16.9 & 93.7 & 133 & صفر & صفر & صفر & صفر & 6.3 & 9 & 4-زواج الزوج من إمراة أخرى. \\
\hline & & & & & & & & & & ب-الآثار بالنسبة للأبناء: \\
\hline الأول & 40.3 & 9.9 & 14 & 23.9 & 34 & 38.7 & 55 & 27.5 & 39 & 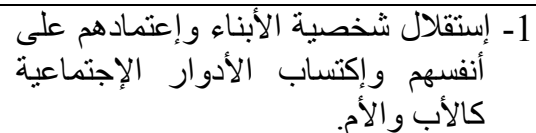 \\
\hline الثانى & 36.2 & 22.5 & 32 & 2.1 & 30 & 35.2 & 50 & 21.1 & 30 & 2- زيادة الإنفاق البذخى للابنباء. \\
\hline الثالث & 35.3 & 19 & 27 & 23.2 & 33 & 47.9 & 68 & 9.9 & 14 & 3-التأثير على النمو النفسى و العقلى للابناء \\
\hline 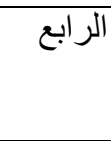 & 34.3 & 21.1 & 30 & 25.4 & 36 & 44.4 & 63 & 9.2 & 13 & 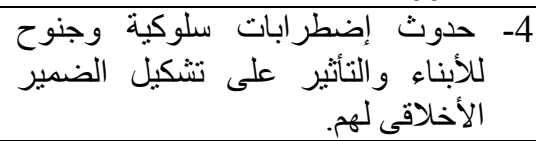 \\
\hline الخامس & 32.7 & 33.8 & 48 & 17.6 & 25 & 33.1 & 47 & 15.5 & 22 & 5- عدم تمسك الأبناء بعادات وقيم المجتمع. \\
\hline السادس & 31.7 & 33.1 & 47 & 25.4 & 36 & 26.8 & 38 & 14.8 & 21 & 6- سوء معاملة الأبناء لمن حولهم. \\
\hline 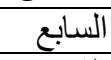 & 29.9 & 38 & 54 & 21.1 & 30 & 33.1 & 47 & 7.7 & 11 & 7- إهمال الأبناء لأداء الفروض الدينية. \\
\hline 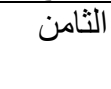 & 29.8 & 40.1 & 57 & 18.3 & 26 & 33.1 & 47 & 8.5 & 12 & 8-إنخفاض. مستوى التحصيل الدراسى \\
\hline & & & & & & & & & & جـالآثار بالنسبة للأسرة: \\
\hline الأول & 49.1 & 2.8 & 4 & 2.1 & 3 & 41.5 & 59 & 53.5 & 76 & 1-زيادة دخل الأسرة وتحسين مستوى \\
\hline 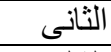 & 46.1 & 6.3 & 9 & 6.3 & 9 & 43.7 & 62 & 43.7 & 62 & 2-شر اء بعض الأصول للأسرة. \\
\hline 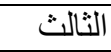 & 45.5 & 6.3 & 9 & 10.6 & 15 & 39.4 & 56 & 43.7 & 62 & 3-تسديد ديون العائلة. \\
\hline 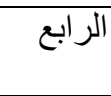 & 44.4 & 7.7 & 11 & 11.3 & 16 & 41.5 & 59 & 39.4 & 56 & 4-مساعدة الوالدين لأداء فريضة الحج أو \\
\hline الخامس & 40.7 & 14.1 & 20 & 11.3 & 16 & 48.6 & 69 & 26.1 & 37 & 5-عمل مشروع صغير لتأمين أفر اد الأسرة. \\
\hline السادس & 35.1 & 26.1 & 37 & 16.2 & 23 & 42.3 & 60 & 15.5 & 22 & 6-مساعدة بعض الأقارب فى السفر. \\
\hline
\end{tabular}

أرناوؤط، أروى رفيق (2000). أثر عمل المرأة المعلمة

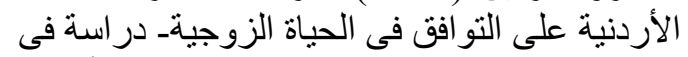
منطقة عمان، رسالة ماجستير، الجامعة الزئة الأرنية،

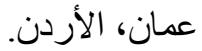
إستيتية، دلال ملحس (2010). التغير الإجتماعى و الثقافى. الطبعة الثالثة، دار وائل للنشر والتوزيع، الأتياعى عمان،

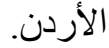
الجهاز المركزى للتعبئة العامة والإحصاء (2014). بيان

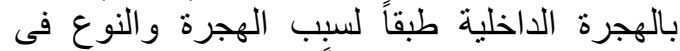

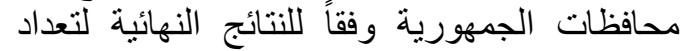

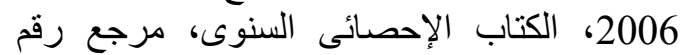
.71-11110-4102 الجهنى، سميرة بنت سالم عياد (2008). عدم الإستقرار

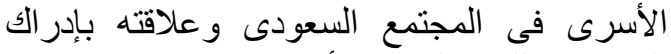
الزوجين للمسئوليات الأسرية ــدراسة مقارنة،

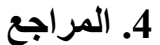

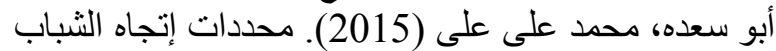

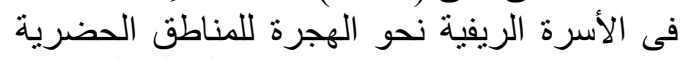

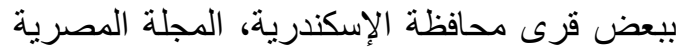

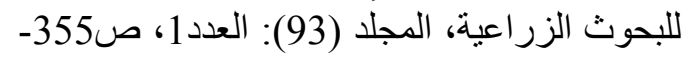
372 أبو غزالة، هيفاء وشرين شكرى (2006). الكاثف في الثى

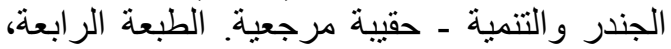

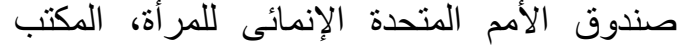
الإقليمى للدول العربية، عمان، الاردن.

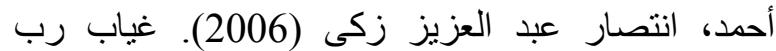
الأسرة وعلاقته بإدارة وقت وجها رئ ربة الأسرة

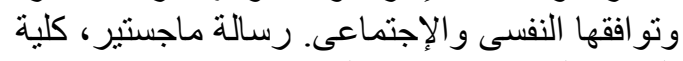

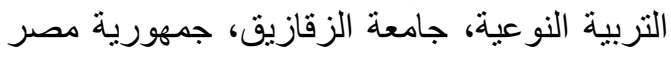

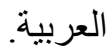


كلية الزراعة، جامعة الزقازيق جمهورية مصر العربية. - الزية

طالح، نصيرة (2011). أثر ضغوط الحياة على الإتجاهات نحو الهجرة إلى الخارج-دراسة ميدانية للطلبة اللية المقبلين على التخرج، رسالة ماجستير، كلية العلوم

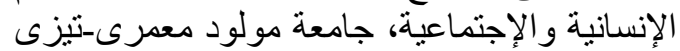

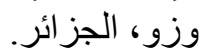

طبال، لطيفة (2012). التغير الإجتماعى ودوره في تغير الإني

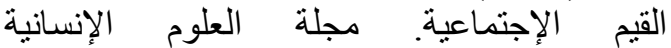

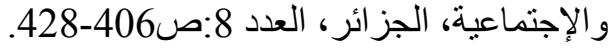

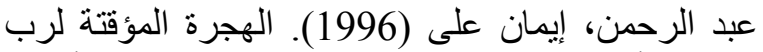

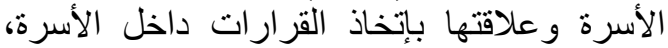

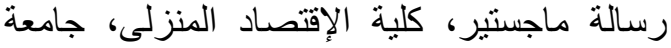
المنوفية جمهورية مصر العربية. عزى، الحسين (2014). الأسرة ودور ها فى التهية تتمية القيم الإجتماعية لدى الطفل فى مرحلة الطفولة الإنة المتأخرة.

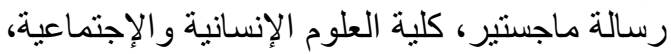

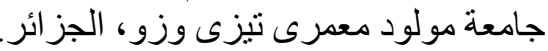

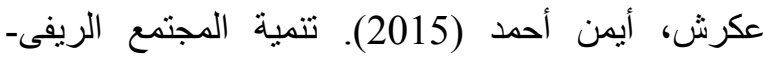
نظريات ونماذج لتحسين جودة الحياة الريفية.

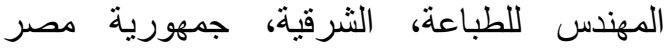

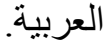

فرج، فلورا إستيرو و الهلالى الثربينى الهلالى والحسينى (إلئى رجب ريحان وإيرينى سمير عبد المسيح الإليح (2005).

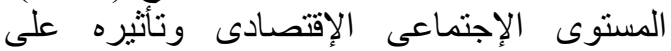
أسلوب إتخاذ القرارات الأسرية. مجلة بحوث التربية النوعية، العدد 6. فهمى، سامية محمد (2003). أدوار المرأة الريفية فئية

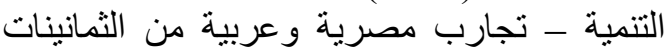

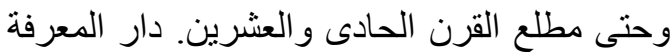

الجامعية، الاسكندرية، جمهورية مصر العئرئية العربية.

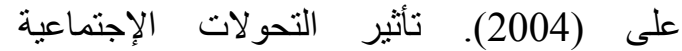

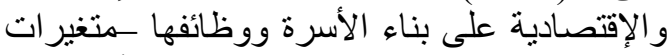
المدخل السوسيولوجى. مؤتمر و واقع الأسرة في الأنى

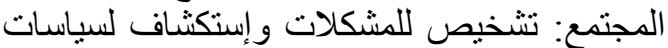
المواجهة، كلية الآداب جامعة عين شمس بلمس بالتعاون

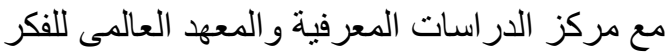

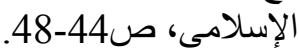

مركز المعلومات ودعم إتخاذ القرار (2015). بيان بقوة العمل بمحافظة الثرقية. مديرية القوى التولة العاملة والهجرة بالشرقية، محافظة الثرقية جمهورية

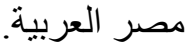

ميسون، سميرة وحمامة الطاهرى (2013). التو افق النفسى النقى النقاء لاى أبناء الآباء ذوى الغياب المتكرر عن البيتــ

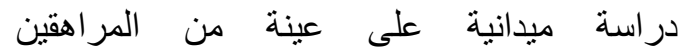
المتمدرسين. الملتقى الوطنى الثنانى حول:الإتصال وجودة الحياة فى الأسرة، كلية العلوم الإنسانيانية الإنسانية و الإجتماعية، جامعة قاصدى مرباح ولاحة ورقلة الجز ائر.

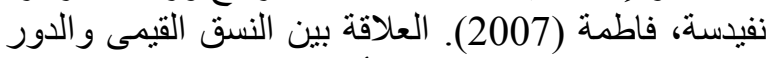
الاجتماعى لدى المرأة الطارقية_دراسة ميدانية النية
رسالة ماجستير، كلية التربية للإقتصاد المنزلى، المعية جامعة أم القرى، المملكة العربية السعودية. الخشاب، سامية مصطفى (بدون سنة). شاهد الفرة على الأسرة الهرة

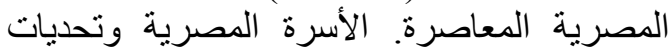

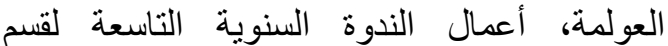
الإجتماع، www.kotobarabia.com الديب، هدى أحمد أحمد ودعاء محمد ذكى حافظ (2015).

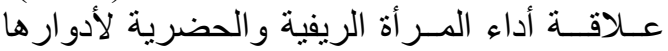

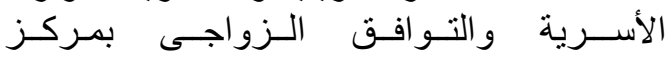
الزقازيق. مجلة الزقازيق للبحوث الزراعية، المجلد

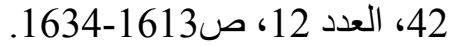

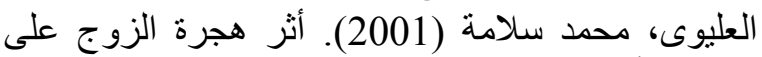

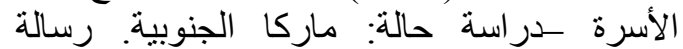
ماجستير، الجامعة الأردنية، عمان، الأردن.

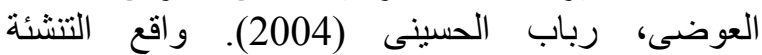
الإجتماعية فى الأسرة، مؤتمر واقع الأسرة فى العى

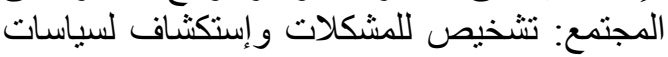

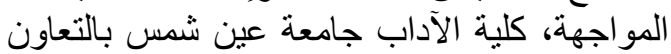

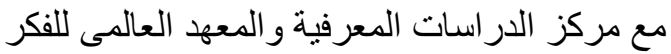

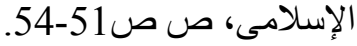
الكندري، أحمد مبارك صكة (1992). علم النفس الأسري، الطبعة الثانية، مكتبة الفلاح الكويت.

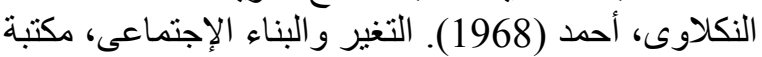

القاهرة الحديثة، القاهرة جمهورية مصر التغين العربية الاجتية.

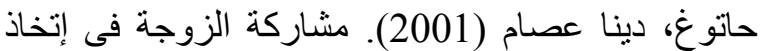

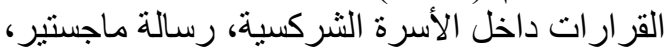
الجامعة الأردنية، عمان، الأردن.

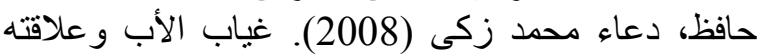

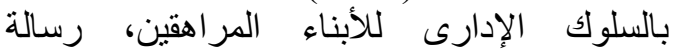
ماجستير، كلية الزر اعة، جامعة الزقازيق جمهورية الرائ

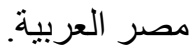

حجازى، مصطفى (2015). الأسرة وصحتها النفسية، ليلة، المقومات_الديناميات_العمليات، الطبرة الطبعة الأولى، الفي، المركز الثقافى العربى، الدار البيضاء، الئياء المغرب.

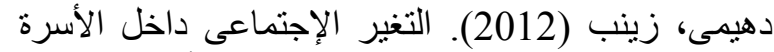

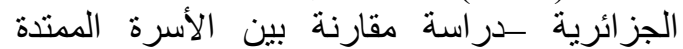

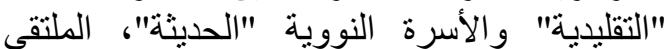

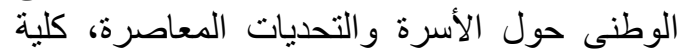

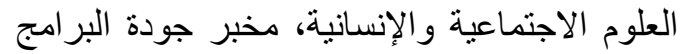

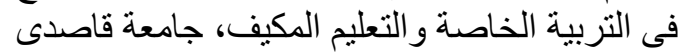
مرباح، ورقلة، الجز ائر.

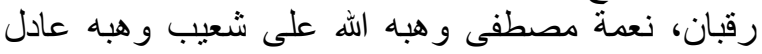
طلعت السرسى (2013). مر اكز المشورة ودور هابها

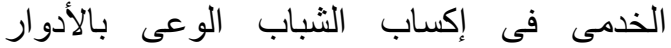

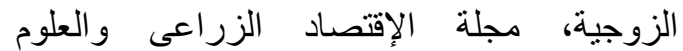
الإجتماعية، جامعة المنصورة، مجلد(4)، الإنهاد، العدد7، 1473-1461 صالح، أمنية محمد البكرى (2007). دور المرأة الريفية فى إدارة المنزل-دراسة مقارنة، رسالة ماجستير، 
أطفالها-در اسة مبدانية لبعض الأمهات العاملات

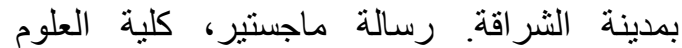

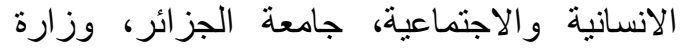

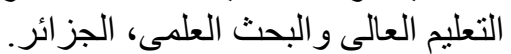

Harrison L. A. and Lynch A. B. (2005).

"Social Role Theory and the Perceived Gender Role Orientation of Athletes. Sex Roles, 52, Nos. 3/4, pp 227-236.

Hahlweg K. (1999). "A Factor Analysis of the Parenting Scale", The Social Learning and the Family Conference, Washington, DC,USA.

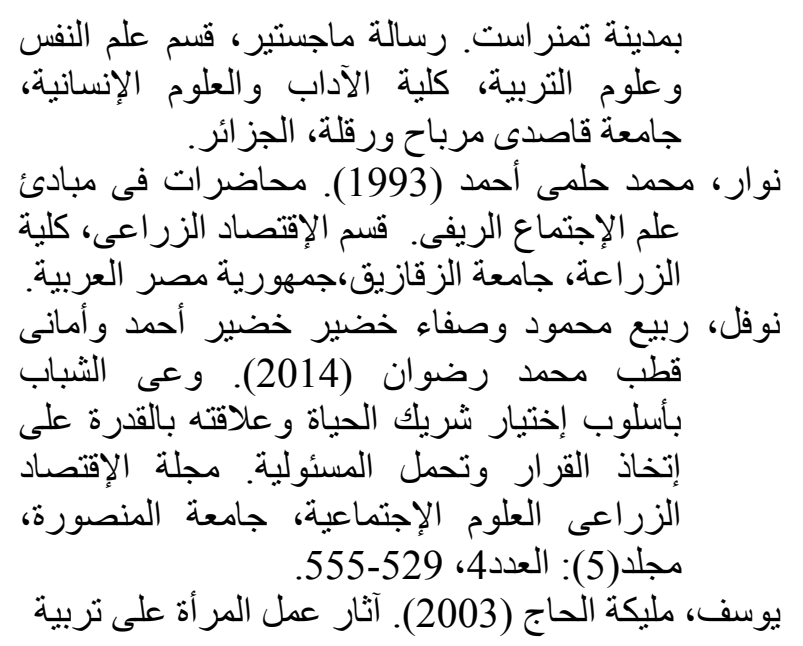

